\title{
DWPF Sample Vial Insert Study-Statistical Analysis of DWPF Mock-Up Test Data
}

by

S. P. Harris

Westinghouse Savannah River Company

Savannah River Site

Aiken, South Carolina 29808

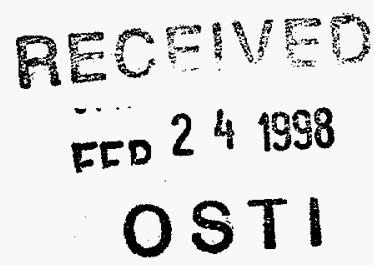

\section{MASTER}

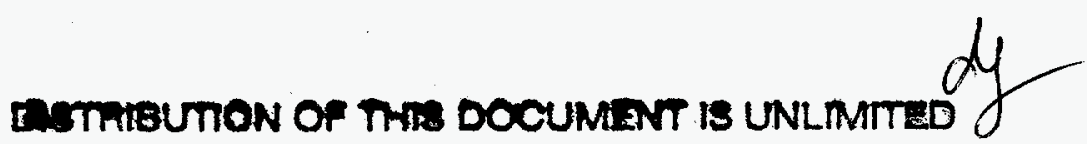

DOE Contract No. DE-AC09-96SR18500

This paper was prepared in connection with work done under the above contract number with the U.S. Department of Energy. By acceptance of this paper, the publisher and/or recipient acknowledges the U.S. Government's right to retain a nonexclusive, royalty-free license in and to any copyright covering this paper, along with the right to reproduce and to authorize others to reproduce all or part of the copyrighted paper. 


\section{DISCLAIMER}

This report was prepared as an account of work sponsored by an agency of the United States Government. Neither the United States Government nor any agency thereof, nor any of their employees, makes any warranty, express or implied, or assumes any legal liability or responsibility for the accuracy, completeness, or usefulness of any information, apparatus, product, or process disclosed, or represents that its use would not infringe privately owned rights. Reference herein to any specific commercial product, process, or service by trade name, trademark, manufacturer, or otherwise does not necessarily constitute or imply its endorsement, recommendation, or favoring by the United States Government or any agency thereof. The views and opinions of authors expressed herein do not necessarily state or reflect those of the United States Government or any agency thereof.

This report has been reproduced directly from the best available copy.

Available to DOE and DOE contractors from the Office of Scientific and Technical Information, P. O. Box 62, Oak Ridge, TN 37831; prices available from (423) 576-8401.

Available to the public from the National Technical Information Service, U. S. Department of Commerce, 5285 Port Royal Road, Springfield, VA 22161. 


\section{DISCLAIMER}

Portions of this document may be illegible electronic image products. Images are produced from the best available original document. 
Westinghouse Savannah River Company Savannah River Technology Center

\title{
DWPF Sample Vial Insert Study
}

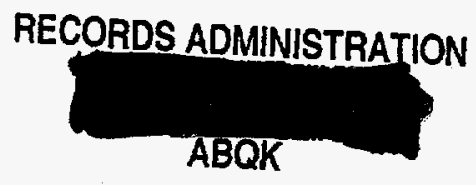

\author{
Statistical Analysis of DWPF Mock-up Test Data( U )
}

Key Words: Hydragard, Insert, Cold Chemical, Mock-up Slurry Mix Evaporator, Melter feed Tank

Retention Period: Permanent

S.P. Harris

September 18, 1997

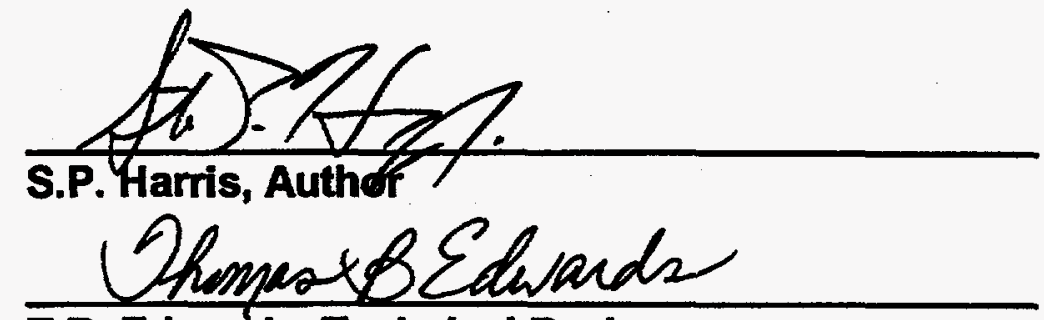

T.B. Edwards, Technical Reviewer

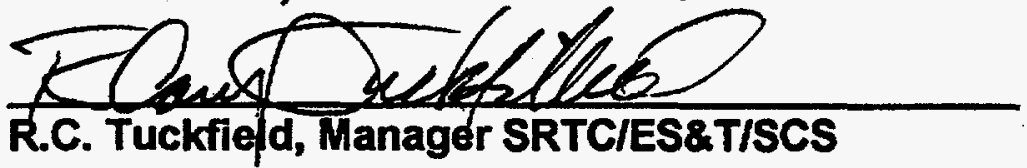

$$
\text { DE/ } 12
$$

D.E. Snyder, DWPF TTR Originator

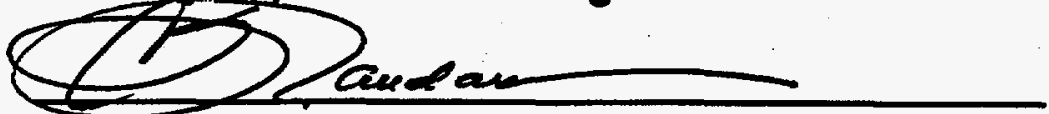

C.T. Randall, Authorized Derivative Classifier
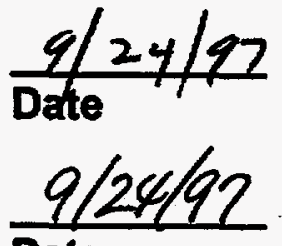

Date

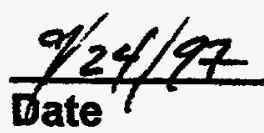

$\frac{9 / 25 / 97}{\text { Date }}$

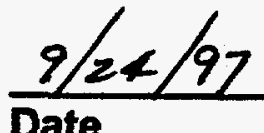




\title{
DWPF Sample Vial Insert Study
}

\section{Statistical Analysis of DWPF Mock-up Test Data( U)}

\author{
S.P. Harris
}

\section{Introduction}

This report is prepared as part of Technical/QA Task Plan WSRC-RP-97-351 which was issued in response to Technical Task Request HLWIDWPF/TTR-970132 submitted by DWPF. Presented in this report is a statistical analysis of DWPF Mock-up test data for evaluation of two new analytical methods which use insert samples from the existing Hydragard $^{\mathrm{TM}}$ sampler. The first is a new hydrofluoric acid based method ${ }^{(1)}$ called the Cold Chemical Method( Cold Chem ) and the second is a modified fusion method.

Either new DWPF analytical method could result in a two to three fold improvement in sample analysis time. Both new methods use the existing Hydragard sampler to collect a smaller insert sample from the process sampling system. The insert testing methodology applies to the DWPF Slurry Mix Evaporator( SME) and the Melter Feed Tank( MFT) samples.

The "insert" sample is named after the initial trials which placed the container inside the sample (peanut) vials. Samples in small $3 \mathrm{ml}$ containers( Inserts ) are analyzed by either the cold chemical method or a modified fusion method. The current analytical method uses a Hydragard sample station to obtain nearly full $15 \mathrm{ml}$ peanut vials. The samples are prepared by a multi-step process for Inductively Coupled Plasma ( ICP ) analysis by drying, vitrification, grinding and finally dissolution by either mixed acid or fusion. In contrast, the insert sample is placed directly in the dissolution vessel, thus eliminating the drying, vitrification and grinding operations for the Cold chem method. Although the modified fusion still requires drying and calcine conversion, the process is rapid due to the decreased sample size and that no vitrification step is required.

A slurry feed simulant material was acquired from the TNX pilot facility from the test run designated as PX-7. The Mock-up test data were gathered on the basis of a statistical design presented in SRT-SCS-97004( Rev. 0 ) $^{\text {(1a) }}$. Simulant PX-7 samples were taken in the DWPF Analytical Cell Mock-up Facility using $3 \mathrm{ml}$ inserts and $15 \mathrm{ml}$ peanut vials. A number of the insert samples were analyzed by Cold Chem and compared with full peanut vial samples analyzed by the current methods. The remaining inserts were analyzed by the modified fusion method, for comparison to the current method, and also 
to obtain a calcine correction factor. The simulant was within $40-42 \mathrm{wt} \%$ solids in order to provide a rheology within the DWPF design range. The rheology at $42 \mathrm{wt} \%$ was approximately 47 dynes $/ \mathrm{cm}^{2}$ yield stress at $25^{\circ} \mathrm{C}$.

\section{Parametric Studies}

During preliminary testing ${ }^{(2)}$ using PX-7 samples taken with a prototypic Hydragard ${ }^{\mathrm{TM}}$ in the 786-A Thermal Fluids Laboratory, the following variables were evaluated for their effect on insert samples relative to full $15 \mathrm{ml}$ peanut vial samples:

Hold time - the time period covering stopping the flow of the material to the time the sample is removed from the station ( $5 \mathrm{sec}, 30 \mathrm{sec}$ );

Vial Flow rate - the measured flow through the sample container( 1, 2, $3 \mathrm{gpm})$;

Valve circulation time - the time material flushed through the sample container( $2,11,20$ sec );

The valve opening/closing rate of the Hydragard ${ }^{\mathrm{TM}}$ sampler was without delay ( fast/fast ). Three insert sizes were considered: $1.5,3$ and $4 \mathrm{ml}$. Six dilutions of PX-7 were used ranging from 34 to 51 wt\%.

Over all tests, the $3 \mathrm{ml}$ insert was the smallest insert that gave comparable sampling results. No discernible difference was found for the $3 \mathrm{ml}$ inserts among the study conditions $^{(3 a, 3 b)}$.

\section{Sample Size for Mock Up Testing}

Reeve suggested that a minimal statistical design for evaluation of a new DWPF analytical method should include a minimum of 4 peanut vial samples taken per shift over six shifts ${ }^{(4)}$ for the current method. Also, the number of samples for the new method is to be determined to insure equivalent variability with regard to the current method.

Since the new method will require conversion of the sample results to a glass equivalent basis, the variation of the proposed calcine correction factor ${ }^{(1 a)}$ was incorporated into the insert size selection. 


\section{Sampling and Analyses}

Samples were pulled according to the insert study Mock-up test design ${ }^{(1 a)}$. Insert samples within each sample block were prepared by either Cold Chem, which is a concentrated hydrofluoric acid digestion carried out at room temperature, or the modified fusion method, which is a scaled up version of the current peroxide/hydroxide method. Two sets of standards were used to mimic the reagents used for the preparations. Instrumental analysis by ICP-AES was under the same calibration per block per dissolution.

Both Dip \& Hydragard ${ }^{\mathrm{TM}} 15 \mathrm{ml}$ samples were prepared using the current methods, microwave assisted mixed acid and hydroxide/peroxide fusion. Two set of standards (mixed acid \& fusion) were used to mimic the reagents in the preparation. Instrumental analysis by ICP-AES was under the same calibration per block per dissolution.

A minimum of three to four lab technicians were to be rotated for sampling, preparation and analysis. The requirement was easily met due to shift environment and the flow of work. For each preparation set, at least two reagent blanks and two analytical reference glass (ARG-1) powders were included with the sample dissolutions.

The DWPF test was performed in 717-10S using a Mock-up facility with physical dimensions similar to analytical cells located in 221-S. All sampling and sample handling was performed in the mock-up cells using remote tools and master slave manipulators. Test conditions were nominally:

Vial Flow Rate ( $1 \mathrm{gpm}$ target )

Valve Circulation Time( $5-10$ sec target)

Valve Opening \& Closing Rate: Nominal (without delay)

Hold Time: Nominal (without delay)

One Feed Type: PX-7 40-42wt\%

The test was to include 6 blocks of samples. Each block represented a discrete event involving startup, operation and shutdown of the sampling system located in 717-10S adjacent to the analytical cells. The test totaled:

12 Dip $15 \mathrm{ml} \mathrm{samples}$

24 Hydragard $^{\mathrm{TM}} 15 \mathrm{ml}$ samples

108 Insert $3 \mathrm{ml}$ samples: ( 54- Cold Chem, 54- Fusion \& Wt\% cal )

( Two samples were identified as outliers \& deleted, Ref. Section 8.) 
One cold chem insert sample and one fusion insert sample were identified as statistical outliers.

\section{Statistical Comparisons}

The statistical analysis includes the following items for satisfying the TTR HLW/DWPF/TTR-970132.

1. Determine the Hydragard ${ }^{\top M}$ sampler bias using the Li/Fe ratio for each method and compare to the $15 \mathrm{ml}$ dip sample results.

2. Compare the elemental wt\% of the new method insert samples versus the current method $15 \mathrm{ml} \mathrm{Hydragard}^{\mathrm{TM}}$ samples. Compute the bias between the new method and the current method.

3. Statistical study of sum of Oxides for Inserts vs Hydragard ${ }^{\mathrm{TM}}$ samples.

As further investigation of any calculated biases, statistical analysis of the check standard, ARG-1, elemental weight percentages and statistical analysis of blank elemental data were conducted. Variability comparisons, calculation of variancecovariance matrices, study of primary properties, determination of number of insert samples such that the variance of the new method is comparable to the variance of the current method are presented in a companion document by C.P. Reeve ${ }^{(7)}$.

\section{Statistical Criteria for the New Method}

The new method, for statistical comparison purposes, should satisfy multiple criteria applied to both the elemental wt\% data and also to the primary property models. The new method's bias should be of no practical significance within the DWPF's Product Composition Control System( PCCS ). A statistical test for bias is applied to the elemental $w t \%$ data in this report. Also, the impact of the calcine or vitrification factor is evaluated. An observed bias could be a result of the sampling method, the analytical method or the result of the correction factor when applied to the insert elemental results.

\section{Analytical Standards}

The ARG-1 check standard is a multicomponent glass standard developed by Corning for use by participants in the Material Characterization Center( MCC) at Pacific Northwest Laboratories. ARG-1 was analyzed at least twice along with each sample 
preparation to evaluate systematic preparation errors. ARG-1 has been well characterized by the MCC. Also, it has been extensively analyzed at the DWPF analytical lab ${ }^{(5)}$. Results from ARG-1 analyzed at DWPF, using the current method, in the time frame of March 1993 to September 8, 1995 are shown in Table 7 for comparison with the Mock-up test data.

\section{Data Outputs}

Data were supplied to SRTC-SCS by the DWPF Analytical Services both electronically and in hard copy (OPS-DTX-970023). The electronically transferred data was validated by SCS using the hard copy.

Data were supplied for microwave assisted mixed acid and peroxide/hydroxide fusion for the current methods, cold chem and fusion along with wt\% calcined correction factor for the new methods. Sample data were statistically screened for outliers with only one sample being eliminated in the cold chem insert sample(Block 2, Pull 7 ) and one sample being eliminated in the fusion insert samples( Block 4, Pull 6 ). Statistical checks for valid data should be developed for routine production use of any new method. Two full blocks of data( Block 3 and Block 6) were not supplied by DWPF Engineering due to known errors in handling of wt\% solids measurements. Two additional blocks were run: Block $7 \& 8$ to replace Blocks 3 and 6 .

\section{Assumptions}

1. The statistical design centers on testing PX-7 feed at one rheology. It is inferred that the results apply to general SME and MFT sample analysis. Parametric testing has shown that varying feed rheologies within the design basis have no adverse effect on the quality of the insert samples when compared to $15 \mathrm{ml}$ Dip and Hydragard ${ }^{\mathrm{TM}}$ samples $^{(3 a, 3 b)}$.

2. Procedural difficulties associated with Blocks 3 and 6 involved the weight \% determinations. Handling delays in taking filled zirconium insert weights greatly expanded the range of values. It is unsure how much of the variation in blocks $1,2,4$ and 5 are related to the handling. Blocks 7 and 8 were weighed without delay once the filled insert was transferred into the zirconium crucible.

3. A constant wt\% solids was expected across all six blocks of data regardless of the method of analysis. This does not appear to be the case using summary statistics from Tables 5 and 6 . Plot 7 shows the graphical comparisons block by block. 


\section{Chart 1}

$\begin{array}{llll} & \begin{array}{l}\text { Solids } \\ w t \%\end{array} & \begin{array}{l}\text { Calcined } \\ w t \%\end{array} & \begin{array}{l}\text { Vitrified } \\ \text { wt\% }\end{array} \\ \text { Dip } & \frac{w t \%}{34.4} \\ \text { Hyd } & 40.1 & - & 33.1 \\ \text { Dip \& Hyd } & 40.2 & - & 33.5 \\ \text { Fusion Inserts } & 42.3 & 36.4 & -\end{array}$

Based on close agreement between the zirconium inserts and additional vials pulled during block 4 which are not included in this report, DWPF Engineering suspects a systematic error in the Dip and Hydragard ${ }^{\mathrm{TM}}$ means. The correct value for wt\% solids is expected to be $42.3 \mathrm{wt} \%$ solids taken from the fusion inserts.

\section{Summary of Statistical Analyses}

Summary statistics and Box-and-Whisker plots have been produced for the PX-7 samples, ARG-1 and blanks for the Mock-up test data. The analysis aids in this report can be studied with regard to specific comparisons of interest.

Separate statistical analyses were done using indicator ratios for the PX-7 samples and also calcine corrected insert data, ARG-1 elementals and elementals for blanks. The ARG-1 summary statistics are shown in Table 8. The established Corning values and DWPF historical ARG-1 results are shown in Table 7. Table 7 contains the statistical results for the current method fusion and mixed acid preparations. These data can be used for comparison purposes with the Mock-up test data. The summary statistics for the blanks are shown in Table 9.

The Box-and-Whisker plots were done for Li/Fe ratios( Plot 1 ), SilLi ratios( Plot 2 ) for PX-7 samples and also the calcine corrected elemental wt\% data(Plot 3). Box-andWhisker plots were also done for the insert fusion data( Plot 4 ) and the ARG-1 elemental wt\%'s ( Plot 5 ). The plots were produced by Statgraphics ${ }^{(6)}$.

Each Box-and-Whisker plot displays the minimum and maximum values, the 25th, 50 th(median) and 75th percentiles. The box is aligned vertically and encloses the interquartile range(the 25th to 75th percentile). The upper part of the box represents the 75th percentile while the lower part represents the 25th percentile. Extreme points, indicated by small boxes or + 's, are shown extending from the box. 


\title{
10.1 Elemental wt\% Relative Differences:
}

\author{
Hydragard $^{T M} 15 \mathrm{ml}$ samples vs $3 \mathrm{~m}$ / insert cold chem samples \\ Hydragard $^{\mathrm{TM}} 15 \mathrm{ml}$ samples vs $3 \mathrm{ml}$ insert fusion samples
}

\section{Cold chemical inserts}

The percent difference between the Hydragard $15 \mathrm{ml}$ and the cold chemical insert data lies within the range $-6.4 \%$ to $-2.2 \%$ for the calcine corrected data and across the major elements as defined as greater than $1.0 \mathrm{wt} \%$ ( Table 3 ). A negative bias ( corrected insert elemental wt\%'s are lower than the peanut vial Hydragard ${ }^{\mathrm{TM}}$ sample wt\%'s) is typically seen for the calcine corrected data( ref. Sec. 11). This bias can be the result of the correction factor, the sampling, and/or the analytical method.

Using a vitrification correction factor and reweighting to a constant wt\% solids, the percent differences lies in the range $-3.1 \%$ to $1.2 \%$ ( Table 3 ). The constant wt\% vitrification corrected data do not typically show a significant bias for the major elementals.

The calcine correction factors and vitrification correction factors are shown in Table 6. The vitrification factors were based on the Hydragard ${ }^{\mathrm{m}}$ peanut vial samples while the calcine correction factors were determined from the fusion inserts.

\section{Fusion inserts}

The percent difference between the Hydragard ${ }^{\mathrm{TM}} 15 \mathrm{ml}$ using the fusion preparation method and the fusion insert data lies within the range -2.7 to $-0.8 \%$ for the calcine basis data and from $0.7 \%$ to $2.7 \%$ for the constant wt\% vitrification corrected data across the major elements ( greater than $1.0 \mathrm{wt} \%$ in Table 4 ). However, the bias is not significant for either case. Comparisons with Hydragard ${ }^{\mathrm{TM}} 15 \mathrm{ml}$ analyses using the mixed acid preparation are shown in Table 4.1. The calcine insert data typically have a significant negative bias ranging between $-5.6 \%$ to $-2.5 \%$ for the major elements except for Si which is positively biased at $+3.4 \%$.

\subsection{Li/Fe Ratios}

The $\mathrm{Li} / \mathrm{Fe}$ ratio is an indicator for the uniformity of the sample which is insensitive to conversion factors. It is a sensitive measurement of the frit to sludge composition since the $\mathrm{Li}$ is exclusively from the Frit and the $\mathrm{Fe}$ is exclusively from the sludge component.

Over all blocks, for insert cold chemical Li/Fe ratios, the difference in means between the $3 \mathrm{ml}$ insert samples and the current method(Mixed Acid) dip $15 \mathrm{ml}$ samples was marginally significant. The average relative difference across all blocks was $-6.3 \%$ ( Table 1.1 ) with a $95 \%$ confidence interval of $-12.7 \%$ to $+0.1 \%$. Over all blocks, for insert fusion Li/Fe ratios; there was also a marginally significant difference in means 
between the insert samples and the fusion dip $15 \mathrm{ml}$ samples. The average relative difference across all blocks was $-6.8 \%$ ( Table 2.1 ) with a $95 \%$ confidence interval of

$-12.7 \%$ to $-0.1 \%$. The relative difference between the insert fusion $\mathrm{Li} / \mathrm{Fe}$ ratios and the current method Mixed Acid dip samples was $-8.1 \%$ ( Table 2.1.1) with a $95 \%$ confidence interval of $-14.1 \%$ to $-2.0 \%$.

The Li/Fe ratios for the Hydragard ${ }^{\mathrm{TM}}$ samples were about $6 \%$ lower than the dip samples for both fusion and mixed acid preparations. This is within expectations based on the Stiemke studies in both magnitude and directions ${ }^{(2)}$ implying that the sample loop and sampling valve provide a technically equivalent sample as compared to the mezzanine installed system in use in 221-S.

The average insert cold chemical Li/Fe ratio lines up very well with the ratio from the current method Hydragard ${ }^{\mathrm{TM}}$ peanut vial samples. This implies that the frit was fully dissolved by the Cold Chem method and that the insert is not impacting the composition of the sample.

\subsection{Silli Ratios}

Silicon and lithium are present in the feed predominately as frit components. The ratio of the two elements should be a constant with some variation associated with the noise of the elemental analysis. The changes in the ratio may indicate losses of silicon as $\mathrm{SiF}_{4}$ or precipitation of silicon as silica or silicon etched from the plasma torch contributing to the analysis.

Over all blocks, for insert cold chemical Si/Li ratios, there was no significant difference in means between the $3 \mathrm{ml}$ insert samples and the mixed acid dip $15 \mathrm{ml}$ samples. The average relative difference across all blocks was $-0.6 \%$ ( Table 1.2 ) with a $95 \%$ confidence interval of $-4.6 \%$ to $+3.5 \%$. The insert fusion SilLi ratios were significantly different than the fusion dip $15 \mathrm{ml}$ samples. The average relative difference across all blocks was $1.8 \%$ ( Table 2.2 ) with a $95 \%$ confidence interval of $0.4 \%$ to $3.3 \%$. The relative difference between the insert fusion $\mathrm{Si} / \mathrm{Li}$ ratios and the mixed acid dip samples was $10.1 \%$ ( Table 2.2.1). The Silli ratios, for the fusion or mixed acid dip samples, were not statistically different than the Hydragard ${ }^{T M}$ peanut vial samples. However, the dip fusion Si/Li ratios( 11.769 ) are typically higher than the dip mixed acid Si/Li ratios (10.997). Similar results hold for the peanut vial Hydragard ${ }^{\mathrm{TM}}$ Si/Li ratios( 11.82 for fusion, 10.95 for mixed acid ). This suggests that any difference is germane to the current methods. 


\subsection{ARG-1}

ARG-1 has been used as a check standard for the insert cold chemical method. However, it does not provide an assessment of the reliability of the calcine factor used to adjust Cold Chemical elemental concentrations. In addition, it does not cover the dissolution process on the compounds originating in the simulant feed.

Box-and-Whisker plots are shown in Plot 5 along with the Corning elemental wt\% means. The ARG-1 average elemental wt\%'s, from Mock-up testing, are comparable to the Corning values except for Si using the Cold Chemical preparation. The Cold Chemical Si wt\% is $7.4 \% \pm 0.9 \%$ lower ( $95 \%$ confidence limits ) than the Corning value ( Chart 2 ). The Si for Insert Cold Chem is also $3.3 \%$ below the Si from the Hydragard ${ }^{\text {TM }}$ peanut vial mixed acid samples which is historically biased low. The variability for the Insert Fusion preparations( Table 8 ) is somewhat greater than historical values ( Table 7 ) while the mixed acid variability is lower. The variability for the insert cold chemical ARG-1 data is comparable to ARG-1 fusion data.

\section{Chart 2}

Corning

Historical (5)

DWPF Fusion

DWPF Mixed Acid

Parametric Test $^{(3 a)}$

Insert Cold Chemical(")

Mock-up

Insert Fusion

Peanut Vial Mixed Acid Insert Cold Chemical $\begin{array}{ll}287 & 23.0\end{array}$

$386 \quad 21.8$

\begin{tabular}{lll}
\hline $\mathbf{N}$ & Average & $\begin{array}{l}\text { Standard } \\
\text { Deviation } \\
\text { wt\% }\end{array}$ \\
\hline
\end{tabular}

22.4

$\begin{array}{lll}37 & 21.7 & 0.809\end{array}$

$\begin{array}{ll}24 & 22.7\end{array}$

0.933

$\begin{array}{ll}13 & 21.4\end{array}$

0.515

$12 \quad 20.7$

0.859

(") Tests 1, 2, 3, 4, reTEST 5 


\subsection{Blanks}

The elemental concentrations for these reagent blanks are known to be zero. The average measurement from a group of such samples processed via an analytical procedure provides an indication of the potential bias in that analytical procedure.

The sample statistics are shown in Table 9 and Box-and-Whisker plots for the various elemental concentrations are shown in Plot 6 . The averages are not large enough to be considered to be of practical importance, except for insert cold chemical Si $0.65 \mathrm{mg} / \mathrm{L}$ ) noted in Chart 3. Thus, the cold chem method may be providing a Si value slightly biased high while the results from section 10.4 indicate that Si values are biased low compared to the current method.

\section{Historical $^{(5)}$}

DWPF Fusion

DWPF Mixed Acid

Parametric Test ${ }^{(3 a)}$

Insert Cold Chemical(")

Mock-up

Insert Fusion

Peanut Vial Mixed Acid

Insert Cold Chemical

\section{Chart 3}

Blanks: Si

N Average $\begin{aligned} & \text { Standard } \\ & \text { Deviation }\end{aligned}$

- mgll $\quad$ mall

$\begin{array}{lll}102 & 0.0514 & 0.0954\end{array}$

$114-0.1935$

0.2072

35

0.135

0.568

$24 \quad-0.0169 \quad 0.0794$

$\begin{array}{lll}13 & -0.0106 & 0.2029\end{array}$

$\begin{array}{lll}12 & 0.6457 & 0.2714\end{array}$

(") Tests $1,2,3,4$, reTEST 5

\section{Corrected Insert wt\%'s}

The wt\% total solids is obtained from the difference between the slurry weight and the weight of the solids after drying at $115^{\circ} \mathrm{C}$. A calcine correction factor $\left(f_{c}\right)$ was obtained by taking the difference between the weight of the slurry before drying and the weight of the oxides after converting most of the compounds to oxides, by heating the sample to between $600^{\circ}$ and $650^{\circ} \mathrm{C}$. Vitrification is the conversion of compounds to a glass 
between $1050^{\circ}$ and $1150^{\circ} \mathrm{C}$. Samples composed of metal salts of hydroxides and nitrates can be calcined easily and the correction factor is proposed as equivalent to vitrification factor. On this basis the calcine factor can be used to convert the elemental results from a slurry basis $\left(I_{s}\right)$ to a calcined basis( $I$ ).

The correction factor for the insert elemental $w t \%$ data is applied as $I=I_{s} / f$ where $f=f_{c}$ or $\mathrm{f}_{\mathrm{v}}$, in this report, depending on if a calcine correction or a vitrification correction is desired. The vitrification correction factor was derived from the Hydragard ${ }^{\mathrm{TM}} \cdot 15 \mathrm{ml}$ peanut vial samples using the current fusion analytical method.

Vitrification results may only be available for the new method as a check on the calcine correction factor. The correction factors can be determined by averaging the wt\% vitrified or the wt\% calcined using the mock-up test data. This assumes that the solids contents of both the peanut vials and inserts are the same. However, this does not appear to be the case in examining the data( Chart 1).

C.P. Reeve has suggested an adjustment for conversion to a vitrified basis. Specifically, let $S_{p v}$ and $S$, be the average total $w$ t\% solids for the peanut vials and the inserts, respectively. The correction factor, for adjusting the fusion insert data to a constant weight percent solids, can be computed as

$$
f=\left(f_{v} / S_{p v}\right) /\left(f_{1} / S_{l}\right)
$$

where $f_{v}$ is a vitrification factor from the peanut vial data and $f_{1}$ is from the fusion insert data. The correction factor $f=0.966$ for the fusion insert data. Similarly, for the cold chemical insert data $f=0.352$.

\section{Oxide Sum}

The sums of oxides for various correction factors applied to the insert cold chemical and insert fusion preparations, appear in Tables 3 and 4 and are summarized in Chart 4. The cold chem dissolution method provides a low sum of oxide recovery ( $91 \%$ ) when calcine corrected. However, the wt\% total solids varies between the different preparation methods. Using a vitrification correction, to constant wt\% solids, increases the sum of oxides for the cold chemical inserts to $94.3 \%$.

Based on the data supplied by TNX, PX-7 is expected to contain small concentrations of materials which were not analyzed for in this test. The sum of oxides may be slightly higher than reported if the non-analyzed materials were determined for the sample. 


\section{Chart 4}

\section{Mock-up Sum of Oxides}

Insert Cold Chemical

Calcine Corrected Block to Block

Calcine Corrected to Overall Block Average

Vitrification Corrected to Constant wt\% Solids
Insert

$91.1 \%$

$91.0 \%$

$94.3 \%$
Hydra (*)

Dip(w)

$96.4 \%$

$96.9 \%$

$96.1 \%\left({ }^{*}\right)$

$99.5 \%$
$97.8 \%$

$98.5 \%$

Calcined Elemental Data

Vitrification Corrected to Constant wt\% Solids

(*) $\mathrm{Na} \& \mathrm{Zr}$ by Cold Chem \& the remaining elements by Fusion

(*) B by Fusion \& the remaining elements by Mixed Acid, Vitrification results are only available for the peanut vial Hydragard ${ }^{\mathrm{TM}}$ and Dip samples.

The correction factor was applied to the insert Cold Chem samples before the oxide gravimetric factors were applied.

\section{Conclusions}

The PX-7 simulant samples from the DWPF Mock-up facility were taken within the range $40-42$ wt\% solids in order to simulate process meology. Preliminary testing ${ }^{(2)}$ using PX-7 samples taken with a prototypic Hydragard ${ }^{T M}$ in the 786-A Thermal Fluids Laboratory has indicated that varying feed compositions and feed rheologies have no adverse effect on the quality of the insert samples.

Statistical analysis of Mock-up testing indicator ratios( $\mathrm{Li} / \mathrm{Fe}, \mathrm{Si} / \mathrm{Li}$ ) has indicated that consistent sampling and analytical performance, relative to the current method, was obtained using $3 \mathrm{ml}$ inserts and the cold chemical preparation method. Over all blocks, for insert cold chemical Li/Fe ratios, there was a marginally significant difference $(-6.3 \%)$ in means between the $3 \mathrm{ml}$ insert samples and the current method(Mixed Acid ) $15 \mathrm{ml}$ dip samples. For insert fusion Li/Fe ratios, there also was a marginally significant difference $(-6.8 \%)$ in means between the insert samples and the fusion dip $15 \mathrm{ml}$ samples. 
For insert cold chemical SilLi ratios, there was not a significant difference $(-0.6 \%)$ in means between the $3 \mathrm{ml}$ insert samples and the mixed acid dip $15 \mathrm{ml}$ samples. The insert fusion Si/Li ratios were significantly different than the fusion dip $15 \mathrm{ml}$ samples.

The ARG-1 average elemental wt\%'s, from Mock-up testing, are comparable to the Corning values except for Si using the Cold Chemical preparation. The Cold Chemical Si wt\% is $7.4 \%$ lower than the Corning value. The cold chem method may be providing a Si value biased relatively high based on analysis of reagent blanks.

The cold chem dissolution method seems to provide a low sum of oxide recovery ( $91 \%$ ) when calcine corrected. However, the wt\% total solids varies between the different preparation methods. Using a vitrification correction, to constant wt\% solids, increases the sum of oxides for the cold chemical inserts to $94.3 \%$.

The percent difference between the calcine correction and the vitrification correction factor should be determined through experimentation and documented. As seen in this report, the choice of the correction factor can have a significant effect on the bias of the Insert Cold Chemical elemental wt\% data. Low ARG-1 recovery values for Si inserts using the Cold Chem preparation method should be investigated further. In addition, the cause of high Si blank wt\%'s should be determined.

Any impact of the biases seen in the comparisons between the new and current methods on the constraints in PCCS was not within the scope of this study. As such, an assessment should be included in the plan for implementation of the new method. 


\section{ATTACHMENTS}

Table 1.1: Summary Statistics for Li/Fe Ratios Insert Cold Chem(ICC) vs Peanut Vial Dip \& PV Hydragard ${ }^{\mathrm{TM}}$ Samples

Table 1.2: Summary Statistics for Si/Li Ratios Insert Cold Chem(ICC) vs Peanut Vial Dip \& PV Hydragard ${ }^{\text {TM }}$ Samples

Table 2.1: Summary Statistics for Li/Fe Ratios Insert Fusions(IF) vs Peanut Vial Dip \& PV Hydragard ${ }^{T M}$ Samples

Table 2.1.1: Summary Statistics for Li/Fe Ratios Insert Fusion( If ) vs Current Method( Mixed Acid) Peanut Vial Samples

Table 2.2: Summary Statistics for Si/Li Ratios Insert Fusions(IF) vs Peanut Vial Dip \& PV Hydragard ${ }^{T M}$ Samples

Table 2.2.1: Summary Statistics for Si/Li Ratios Insert Fusion( IF ) vs Current Method( Mixed Acid) Peanut Vial Samples

Table 3: Bias for Insert Cold Chemical Elemental wt\% Data SCREENED for Outliers

Table 4: Bias for Insert Fusion Elemental wt\% Data Peanut Vial Fusion SCREENED for Outliers

Table 4.1: Bias for Insert Fusion Elemental wt\% Data Peanut Vial Mixed Acid SCREENED for Outliers

Table 5: Summary of wt\% Solids 
Table 6: Summary of PV Vitrified Solids \& Insert Calc Solids

Table 7: Historical ARG-1 from SRT-ASG-95-0081

Table 8: Sample Statistics for ARG-1 from MOCK-up Test

Table 9: Sample Statistics for BLANKS from MOCK-up Test

Plot 1: Box-and Whisker Plots: Li/Fe Ratio

Plot 2: Box-and Whisker Plots: Si/Li Ratio

Plot 3: Box-and Whisker Plots: Calcine Corrected Insert Cold Chemical Elemental wt\% data

Plot 4: Box-and Whisker Plots: Insert Fusion Elemental wt\% data

Plot 5: Box-and Whisker Plots: ARG-1 Elemental wt\% data

Plot 6: Box-and Whisker Plots: Blank Elemental wt\% data

Plot 7: Box-and Whisker Plots: wt\% Total Solids, wt\% Vitrified \& wt\% Calcined Solids 


\section{References}

(1) C.J. Coleman and S.R. Goode, "DWPF Sample Vial Inserts( U )", WSRC-TR-950205, May 31, 1995.

(1a) S.P. Harris, "DWPF Sample Vial Insert Study: Mock-up Testing Study Design ( U )", SRT-SCS-97004( Rev. 0), March 31, 1997.

(2) J.L. Steimke, "Testing of Hydragard ${ }^{\mathrm{TM}}$ Sampling System with Vial Inserts( U )", WSRC-TR-97-0218, July, 1997.

(3a) S.P. Harris, "DWPF Sample Vial Insert Study: Statistical Analysis of Parametric Data( U )", SRT-SCS-97006( Rev. 1), March 10, 1997.

(3b) R.S. Beck, "Results of Scoping Work for Insert Use at DWPF( U )", WSRC-TR97-0076, March, 1997.

(4) C.P. Reeve, " A Statistical Plan for Evaluating a New DWPF Laboratory Analytical Method(U )", WSRC-TR-96-0098, April 16, 1996.

(5) S.P. Harris, "DWPF ARG-1 Glass Composition( U )", SRT-ASG-95-0081, March 11, 1996.

(6) Statgraphics Plus, Version 6.0, Statistical Graphics Corporation and Manugistics, Inc.

(7) C.P. Reeve, "Covariance Matrices for Direct Dissolution of Vial Insert Samples in DWPF Mock-up Facility(U), WSRC-TR-97-00286. 


\section{Table 1.1}

\section{Summary Statistics for Li/Fe Ratios}

Insert Cold Chem(ICC) vs Peanut Vial Dip \& PV Hydragard ${ }^{\mathrm{TM}}$ Samples $^{\mathrm{N}}$

(M): Current Method Mixed Acid

Block ICC Dip(M) Hyd(M) ICC-Dip(M) Hyd(M)-Dip(M)

$\begin{array}{llll} & \text { N } & \begin{array}{l}\text { Li/Fe } \\ \text { Avg }\end{array} & \text { N } \\ & & & \\ 1 & 9 & 0.240 & 2 \\ 2 & 9 & 0.238 & 2 \\ 4 & 8 & 0.261 & 2 \\ 5 & 9 & 0.256 & 2 \\ 7 & 9 & 0.262 & 2 \\ 8 & 9 & 0.252 & 2\end{array}$

Li/fe N
Avg

LuFe

Avg

Avg

$\begin{array}{ll}0.272 & 4 \\ 0.270 & 4 \\ 0.273 & 4 \\ 0.275 & 4 \\ 0.250 & 4 \\ 0.270 & 4\end{array}$

0.249

0.248

0.263

0.251

0.248

0.250

$\begin{array}{ll}-0.0322^{*} & -0.0232^{*} \\ -0.0319^{*} & -0.0218 \\ -0.0124 & -0.0101 \\ -0.0194 & -0.0240^{*} \\ 0.0126 & -0.0012 \\ -0.0181 & -0.0195\end{array}$

0.2683

$-0.0169(-6.3 \%)-0.0166(-6.2 \%)$

95\% Conf:

Upper

Lower

$\begin{array}{ll}\frac{\text { ICC-Dip(M) }}{0.0004(0.1 \%)} & \text { Hyd(M)-Dip(M) } \\ -0.00342(-12.7 \%) & -0.0262(-2.7 \%) \\ -0.03 \%)\end{array}$

* Significant based on $95 \%$ Confidence \& Least Significant Differences 
Table 1.2

\section{Summary Statistics for Si/Li Ratios}

Insert Cold Chem(ICC) vs Peanut Vial Dip \& PV Hydragard ${ }^{\mathrm{TM}}$ Samples $^{\mathrm{T}}$

(M): Mixed Acid

Block ICC. $\underline{\operatorname{Dip}(M)}$ Hyd(M) ICC-Dip(M) Hyd(M)-Dip(M)

$\begin{array}{lllllllll} & \mathbf{N} & \begin{array}{l}\text { Silli } \\ \text { Avg }\end{array} & \mathbf{N} & \begin{array}{l}\text { Si/Li } \\ \text { Avg }\end{array} & \mathbf{N} & \begin{array}{l}\text { Silli } \\ \text { Avg }\end{array} & \\ & & & & & & & \\ 1 & 9 & 11.159 & 2 & 10.819 & 4 & 10.891 & 0.340 & 0.072 \\ 2 & 9 & 10.993 & 2 & 10.630 & 4 & 10.764 & 0.363 & 0.134 \\ 4 & 8 & 10.795 & 2 & 10.706 & 4 & 10.719 & 0.089 & 0.013 \\ 5 & 9 & 10.526 & 2 & 10.717 & 4 & 10.847 & -0.191 & 0.130 \\ 7 & 9 & 10.723 & 2 & 11.496 & 4 & 11.549 & -0.773^{*} & 0.054 \\ 8 & 9 & 10.721 & 2 & 10.955 & 4 & 10.922 & -0.235 & -0.033 \\ \text { Avg } & & & & 10.887 & & -0.068(-0.6 \%) & 0.062(+0.6 \%)\end{array}$

95\% Conf:

Upper
Lower

ICC-Dip(M) Hyd(M)-Dip(M)

$0.382(+3.5 \%) \quad 0.130(+1.2 \%)$

$-0.517(-4.6 \%) \quad-0.007(-0.1 \%)$

* Significant based on $95 \%$ Confidence \& Least Significant Differences 
Table 2.1

\section{Summary Statistics for Li/Fe Ratios}

\section{Insert Fusions(IF) vs Peanut Vial Dip \& PV Hydragard ${ }^{\text {TM }}$ Samples}

(F): Fusion

Block IF Dip(F) $\operatorname{Hrd}(F)$ IF-Dip(F) Hrd(F)-Dip(F)

$\begin{array}{llll} & \text { N } & \begin{array}{l}\text { Li/Fe } \\ \text { Avg }\end{array} & \text { N } \\ & & & \\ 1 & 9 & 0.234 & 2 \\ 2 & 6 & 0.241 & 2 \\ 4 & 7 & 0.255 & 2 \\ 5 & 7 & 0.251 & 2 \\ 7 & 8 & 0.257 & 2 \\ 8 & 8 & 0.243 & 2\end{array}$

Life
Avg

Li/Fe Avg

Avg

$\begin{array}{ll}0.273 & 4 \\ 0.267 & 4 \\ 0.264 & 4 \\ 0.271 & 4 \\ 0.253 & 4 \\ 0.259 & 4 \\ & 0.2646\end{array}$

0.251

$0.245-0.0262 *$

$-0.0222$

$0.254-0.0095$

$-0.0222$

$0.248 \quad-0.0205$

$-0.0099$

$\begin{array}{ll}0.250 & 0.0041\end{array}$

0.0236

$0.244-0.0163$

$-0.0155$

95\% Conf:

Upper

IF-Dip(F)

$-0.0024(-0.1 \%)$

$-0.0335(-12.7 \%)$

Hyd(F)-Dip(F)

$-0.0070(-2.6 \%)$

$-0.0249(-9.4 \%)$

* Significant based on $95 \%$ Confidence \& Least Significant Differences 
Table 2.1.1

\section{Summary Statistics for Li/Fe Ratios}

Insert Fusion( IF ) vs Current Method Peanut Vial Samples

(M): Current Method Mixed Acid

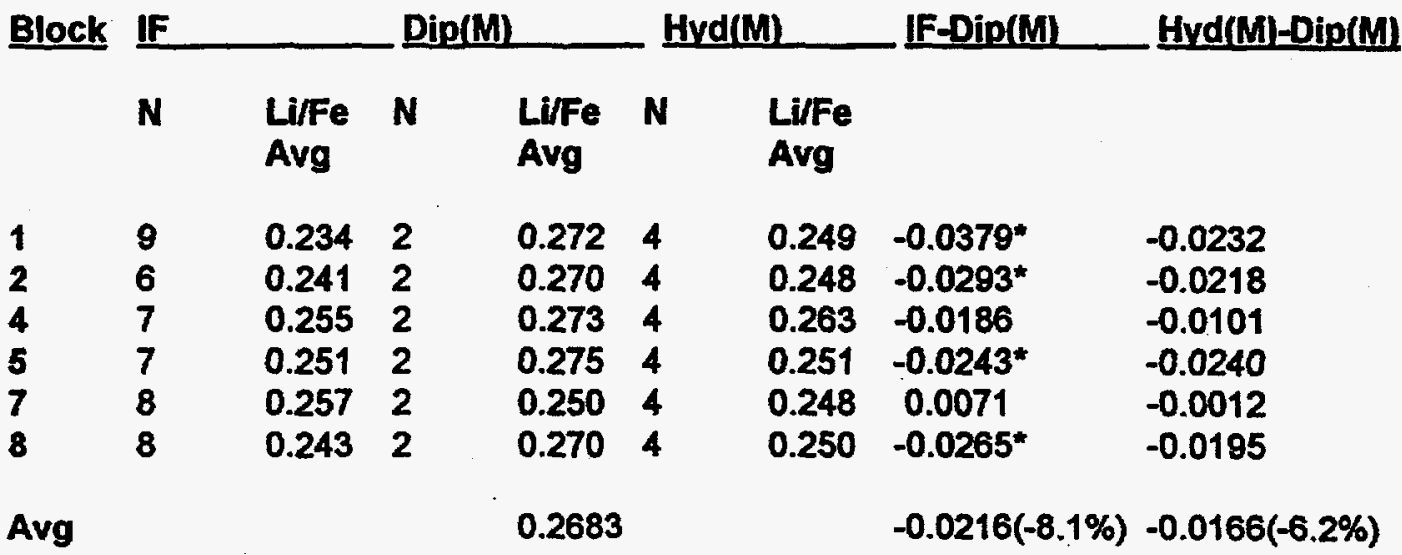

95\% Conf:

Upper

IF-Dip(M) Hyd(M)-Dip(M)

Lower

$-0.0054(-2.0 \%) \quad-0.0071(-2.7 \%)$

$-0.0378(-14.1 \%)-0.0262(-9.8 \%)$

- Significant based on $95 \%$ Confidence \& Least Significant Differences 
Table 2.2

\section{Summary Statistics for Si/Li Ratios}

\section{Insert Fusions(IF) vs Peanut Vial Dip \& PV Hydragard ${ }^{\mathrm{TM}}$ Samples}

(F): Fusion

Block $\underline{\mathbf{F}}$ $\operatorname{Dip}(\mathbf{F})$ Hyd(F) Hyd(F)-Dip(F)

$\begin{array}{llll} & \text { N } & \begin{array}{l}\text { Si/Li } \\ \text { Avg }\end{array} & \text { N } \\ & & & \\ 1 & 9 & 11.880 & 2 \\ 2 & 6 & 11.944 & 2 \\ 4 & 7 & 12.021 & 2 \\ 5 & 7 & 11.988 & 2 \\ 7 & 8 & 12.043 & 2 \\ 8 & 8 & 12.040 & 2\end{array}$

Silli N
Avg

Silli

11.6084

11.9714

11.6954

11.6304

11.7074

12.0034

11.769
F-Dip(F)

Avg

95\% Conf:

\section{Upper} Lower

IF-Dip(F) Hyd(F)-Dip(F) $0.393(+3.3 \%) \quad 0.162(1.4 \%)$ $0.042(0.4 \%)-0.065(-0.6 \%)$

- Significant based on 95\% Confidence \& Least Significant Differences 


\section{Table 2.2.1}

\section{Summary Statistics for Si/Li Ratios}

Insert Fusion( IF ) vs Current Method Peanut Vial Samples

(M): Current Method Mixed Acid

Block IF Dip(M) Hrd(M) F-Dip(M) Hrd(M)-Dip(M)

$\begin{array}{llll} & \mathbf{N} & \begin{array}{l}\text { Si/Li } \\ \text { Avg }\end{array} & \text { N } \\ 1 & 9 & 11.880 & 2 \\ 2 & 6 & 11.944 & 2 \\ 4 & 7 & 12.021 & 2 \\ 5 & 7 & 11.988 & 2 \\ 7 & 8 & 12.043 & 2 \\ 8 & 8 & 12.040 & 2\end{array}$

Sili N
Avg

Si/Li

Avg

Avg

10.8194

10.891

10.764

$1.0613^{*}$

0.072

10.6304

10.719

$1.3144^{*}$

0.134

10.7064

$10.8471 .2710^{*}$

0.013

10.7174

0.130

11.4964

11.549

$0.5469^{*}$

0.054

10.9554

10.922

$1.0850^{*}$

$-0.033$

10.887

$1.0989(10.1 \%) 0.062(+0.6 \%)$

95\% Conf:

Upper
Lower

IF-Dip(M) Hyd(M)-Dip(M)

$1.406(12.8 \%) \quad 0.130(+1.2 \%)$

$0.791(7.3 \%)-0.007(-0.1 \%)$

- Significant based on 95\% Confidence \& Least Significant Differences 


\section{Table 3}

\section{Bias for Insert Cold Chemical Elemental wt\% Data SCREENED for Outliers}

Hyd: Hydragard ${ }^{\mathrm{TM}}$ Peanut Vial Samples using the Current Method,

B from Fusion \& remaining elements from Mixed Acid

ICC: Insert Cold Chem

Bias: ICC - Hyd

Avg Percent Bias $=100($ ICC + Hyd $) /$ Hyd

Lo, Up: Lower \& Upper 95\% Confidence Limits

\section{Calcine Corrected Block to Block}

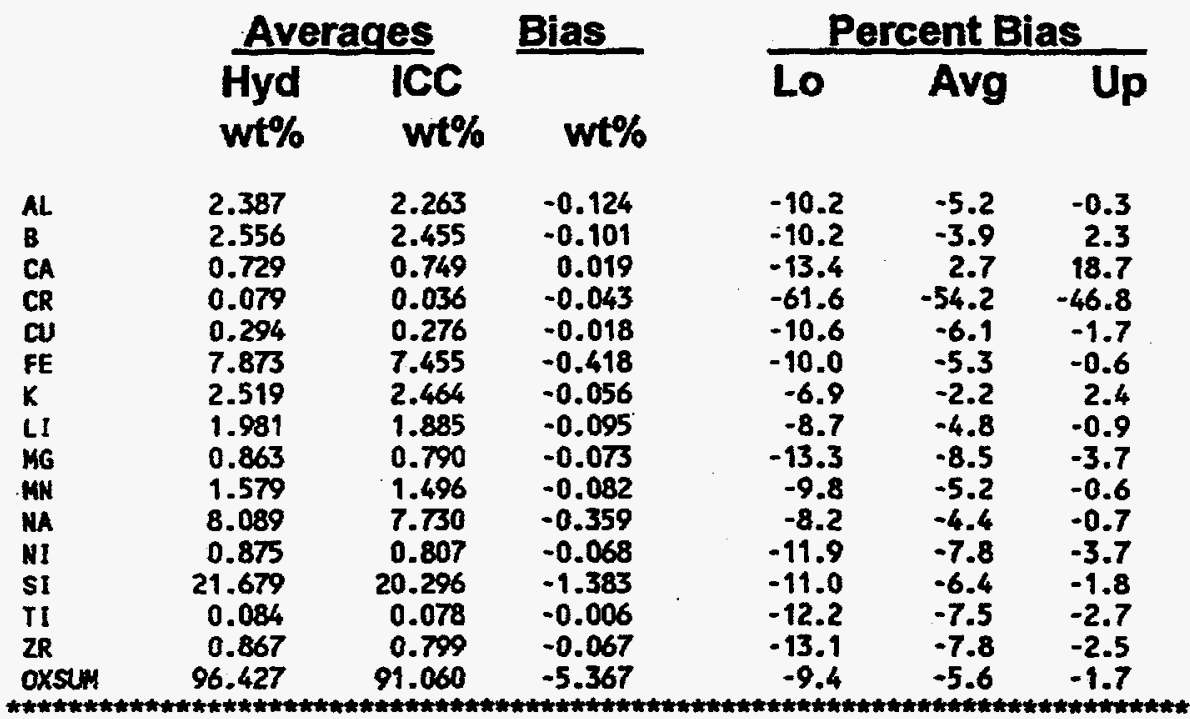

Calcine Corrected to Overall Block Average

\begin{tabular}{|c|c|c|c|c|c|c|}
\hline & Ave & ges & Bias & 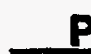 & en & $S$ \\
\hline & $\begin{array}{l}\text { Hyd } \\
\text { wt\% }\end{array}$ & $\begin{array}{l}\text { ICC } \\
\text { wt } \%\end{array}$ & $w+\%$ & Lo & Avg & $\mathrm{Up}$ \\
\hline $\begin{array}{l}\text { AL } \\
\text { B } \\
\text { CA } \\
\text { CR } \\
\text { CU } \\
\text { FE } \\
K \\
\text { LI } \\
\text { MG } \\
\text { MN } \\
\text { NA } \\
\text { NI } \\
\text { SI } \\
\text { II } \\
\text { ZR } \\
\text { OXSUM }\end{array}$ & $\begin{array}{r}2.387 \\
2.556 \\
0.729 \\
0.079 \\
0.294 \\
7.873 \\
2.519 \\
1.981 \\
0.863 \\
1.579 \\
8.089 \\
0.875 \\
21.679 \\
0.084 \\
0.867 \\
96.427\end{array}$ & $\begin{array}{r}2.262 \\
2.457 \\
0.749 \\
0.036 \\
0.275 \\
7.452 \\
2.463 \\
1.885 \\
0.790 \\
1.496 \\
7.729 \\
0.807 \\
20.291 \\
0.078 \\
0.799 \\
91.041\end{array}$ & $\begin{array}{r}-0.125 \\
-0.099 \\
0.019 \\
-0.043 \\
-0.018 \\
-0.421 \\
-0.057 \\
-0.095 \\
-0.073 \\
-0.083 \\
-0.360 \\
-0.068 \\
-1.389 \\
-0.006 \\
-0.068 \\
-5.386\end{array}$ & $\begin{array}{r}-9.5 \\
-11.4 \\
-14.2 \\
-61.6 \\
-9.7 \\
-8.9 \\
-5.7 \\
-8.1 \\
-11.9 \\
-8.8 \\
-7.3 \\
-11.4 \\
-10.1 \\
-11.5 \\
-12.2 \\
-8.7\end{array}$ & $\begin{array}{r}-5.2 \\
-3.9 \\
2.7 \\
-54.2 \\
-6.2 \\
-5.3 \\
-2.3 \\
-4.8 \\
-8.5 \\
-5.2 \\
-4.5 \\
-7.8 \\
-6.4 \\
-7.5 \\
-7.8 \\
-5.6\end{array}$ & $\begin{array}{r}-1.0 \\
3.7 \\
19.5 \\
-46.8 \\
-2.6 \\
-1.8 \\
1.2 \\
-1.6 \\
-5.1 \\
-1.7 \\
-1.7 \\
-4.2 \\
-2.8 \\
-3.5 \\
-3.5 \\
-2.5\end{array}$ \\
\hline
\end{tabular}




\section{Table 3}

(Continued)

\section{Vitrification Corrected to Constant wt\% Solids}

\begin{tabular}{|c|c|c|c|c|c|c|}
\hline & \multicolumn{2}{|c|}{ Averages } & \multirow{2}{*}{$\begin{array}{l}\text { Bias } \\
\text { wt\% }\end{array}$} & \multicolumn{3}{|c|}{ Percent Bias } \\
\hline & $\begin{array}{l}\text { Hyd } \\
\text { wt\% }\end{array}$ & $\begin{array}{l}\text { ICC } \\
w t \%\end{array}$ & & Lo & Avg & $\overline{U p}$ \\
\hline $\begin{array}{l}\text { AL } \\
\text { B } \\
\text { CA } \\
\text { CR } \\
\text { CU } \\
\text { FE } \\
K \\
\text { LI } \\
\text { MG } \\
\text { MN } \\
\text { MA } \\
\text { HI } \\
\text { SI } \\
\text { TI } \\
\text { 2R } \\
\text { OXSUH }\end{array}$ & $\begin{array}{r}2.387 \\
2.556 \\
0.729 \\
0.079 \\
0.294 \\
7.873 \\
2.519 \\
1.981 \\
0.863 \\
1.579 \\
8.089 \\
0.875 \\
21.679 \\
0.084 \\
0.867 \\
96.427\end{array}$ & $\begin{array}{r}2.342 \\
2.543 \\
0.775 \\
0.038 \\
0.285 \\
7.716 \\
2.550 \\
1.952 \\
0.817 \\
1.549 \\
8.002 \\
0.835 \\
21.008 \\
0.081 \\
0.827 \\
94.260\end{array}$ & $\begin{array}{r}-0.045 \\
-0.012 \\
0.046 \\
-0.042 \\
-0.008 \\
-0.157 \\
0.030 \\
-0.029 \\
-0.045 \\
-0.030 \\
-0.087 \\
-0.040 \\
-0.671 \\
-0.004 \\
-0.040 \\
-2.167\end{array}$ & $\begin{array}{r}-6.2 \\
-8.3 \\
-11.0 \\
-60.1 \\
-6.5 \\
-5.6 \\
-2.3 \\
-4.8 \\
-8.7 \\
-5.5 \\
-3.9 \\
-8.2 \\
-6.8 \\
-8.3 \\
-9.0 \\
-5.4\end{array}$ & $\begin{array}{r}-1.9 \\
-0.5 \\
6.3 \\
-52.6 \\
-2.9 \\
-2.0 \\
1.2 \\
-1.4 \\
-5.3 \\
-1.9 \\
-1.1 \\
-4.6 \\
-3.1 \\
-4.2 \\
-4.6 \\
-2.2\end{array}$ & $\begin{array}{r}2.4 \\
7.3 \\
23.6 \\
-45.1 \\
0.8 \\
1.6 \\
4.7 \\
1.9 \\
-1.8 \\
1.7 \\
1.8 \\
-0.9 \\
0.7 \\
-0.2 \\
-0.1 \\
0.9\end{array}$ \\
\hline
\end{tabular}


Table 4.1

\section{Bias for Insert Fusion Elemental wt\% Data SCREENED for Outliers}

Hyd: Hydragard ${ }^{\mathrm{TM}}$ Mixed Acid Peanut Vial Samples using the Current Method IF: Insert Fusion

Bias: IF - Hyd

Avg Percent Bias= 100( IF-Hyd)/Hyd

Lo, Up: Lower \& Upper 95\% Confidence Limits

Fusion Inserts( Calcine Basis ) Elemental Data

Averages Bias

Hyd IF

$w t \%$

$\begin{array}{rrr}2.387 & 2.265 & -0.122 \\ 2.556 & 2.486 & -0.069 \\ 0.729 & 0.603 & -0.126 \\ 0.079 & 0.085 & 0.006 \\ 0.294 & 0.278 & -0.015 \\ 7.873 & 7.666 & -0.207 \\ 2.519 & 2.397 & -0.122 \\ 1.981 & 1.870 & -0.111 \\ 0.863 & 0.822 & -0.041 \\ 1.579 & 1.524 & -0.055 \\ 8.089 & 7.887 & -0.202 \\ 0.875 & 0.829 & -0.046 \\ 21.679 & 22.424 & 0.744 \\ 0.084 & 0.080 & -0.004 \\ 0.867 & 0.816 & -0.051 \\ 96.427 & 96.137 & -0.291\end{array}$

Percent Bias

Lo Avg Up

$\begin{array}{rrr}-8.9 & -5.1 & -1.4 \\ -5.0 & -2.7 & -0.4 \\ -26.2 & -17.3 & -8.4 \\ -28.6 & 7.2 & 43.1 \\ -9.2 & -5.3 & -1.3 \\ -7.8 & -2.6 & 2.6 \\ -8.8 & -4.9 & -0.9 \\ -8.5 & -5.6 & -2.7 \\ -7.1 & -4.7 & -2.3 \\ -7.1 & -3.5 & 0.2 \\ -4.3 & -2.5 & -0.7 \\ -9.4 & -5.2 & -1.0 \\ 0.0 & 3.4 & 6.9 \\ -9.2 & -4.6 & 0.1 \\ -11.2 & -5.9 & -0.5 \\ -3.4 & -0.3 & 2.8\end{array}$

Fusion Inserts Vitrification Corrected to Constant wt\% Solids \begin{tabular}{lll}
\multicolumn{2}{c}{ Averages } & Bias \\
Hyd & IF & \\
wt $\%$ & wt $\%$
\end{tabular}

$\begin{array}{lrrrrrr}\text { AL } & 2.387 & 2.345 & -0.042 & -5.6 & -1.8 & 2.1 \\ \text { B } & 2.556 & 2.574 & 0.019 & -1.6 & 0.7 & 3.1 \\ \text { CA } & 0.729 & 0.624 & -0.105 & -23.4 & -14.4 & -5.3 \\ \text { CR } & 0.079 & 0.088 & 0.009 & -26.0 & 11.0 & 48.0 \\ \text { CU } & 0.294 & 0.288 & -0.006 & -5.9 & -1.9 & 2.1 \\ \text { FE } & 7.873 & 7.937 & 0.064 & -4.5 & 0.8 & 6.2 \\ \text { K } & 2.519 & 2.482 & -0.037 & -5.5 & -1.5 & 2.5 \\ \text { LI } & 1.981 & 1.936 & -0.044 & -5.2 & -2.2 & 0.7 \\ \text { MG } & 0.863 & 0.851 & -0.011 & -3.8 & -1.3 & 1.1 \\ \text { MW } & 1.579 & 1.578 & -0.001 & -3.7 & 0.0 & 3.7 \\ \text { HA } & 8.089 & 8.166 & 0.077 & -0.8 & 1.0 & 2.7 \\ \text { HI } & 0.875 & 0.859 & -0.017 & -6.2 & -1.9 & 2.4 \\ \text { SI } & 21.679 & 23.217 & 1.538 & 3.6 & 7.1 & 10.6 \\ \text { II } & 0.084 & 0.083 & -0.001 & -5.9 & -1.2 & 3.5 \\ \text { ZR } & 0.867 & 0.845 & -0.022 & -8.0 & -2.5 & 2.9 \\ \text { OXSUN } & 96.427 & 99.540 & 3.112 & 0.1 & 3.2 & 6.4\end{array}$




\section{Table 5}

\section{Summary of wt\% Total Solids}

The coefficient of variation: $C V=100$ ( Standard Deviation V/ Average

Peanut Vial Dip \& Hydragard ${ }^{T M}$ data were combined since there is no statistical difference in $w t \%$ data.

\begin{tabular}{|c|c|c|c|c|c|c|c|c|c|c|c|c|}
\hline \multirow[t]{2}{*}{ Block } & \multicolumn{3}{|c|}{ Peanut Vial Dip. } & \multicolumn{3}{|c|}{ Peanut Vial Hyd } & \multicolumn{3}{|c|}{ Dip \& Hyd } & \multicolumn{3}{|c|}{ Fusion Inserts } \\
\hline & $\bar{N}$ & $\begin{array}{l}\text { Avg } \\
\text { wt\% } \\
\text { Sol } \\
\end{array}$ & $\begin{array}{l}\text { CV } \\
\% \\
\end{array}$ & $\mathbf{N}$ & $\begin{array}{l}\text { Avg } \\
\text { wt\% } \\
\text { Sol } \\
\end{array}$ & $\%$ & $\mathbf{N}$ & $\begin{array}{l}\text { Avg } \\
\text { wt\% } \\
\text { Sol } \\
\end{array}$ & CV & $\mathbf{N}$ & $\begin{array}{l}\text { Avg } \\
\text { wt\% } \\
\text { Sol } \\
\end{array}$ & CV \\
\hline & 2 & & & 4 & & & 6 & .73 & & 9 & & \\
\hline 2 & 2 & & & 2 & & & $\epsilon$ & 13 & & 8 & & \\
\hline & 2 & & 0. & 4 & 37.71 & 8. & 6 & .77 & & 9 & 33 & \\
\hline & 2 & & 1. & 4 & & 6. & 6 & 24 & & 9 & 47 & 2. \\
\hline & 2 & 4 & 0. & 4 & & 0. & 6 & 41.17 & & 9 & 99 & \\
\hline & 2 & 40.68 & $0.2 \%$ & 4 & 40.26 & $1.0 \%$ & 6 & 40.40 & $0.9 \%$ & 8 & 41.68 & \\
\hline rs & 12 & 40.61 & $2.5 \%$ & 24 & 40.06 & $2.3 \%$ & 36 & 40.24 & $4.8 \%$ & 52 & 42.26 & $3.5 \%$ \\
\hline
\end{tabular}

\begin{tabular}{lll} 
Block & & Diffl \\
\cline { 1 - 1 } & & wt\% \\
1 & & 1.55 \\
2 & & 3.82 \\
4 & & 3.56 \\
5 & & 1.23 \\
7 & 0.82 \\
8 & & 1.28
\end{tabular}

Avg $\quad 2.04$

95\% Conf Limits:

Upper $\quad 3.41$

Lower $\quad 0.68$ 
Table 6

\section{Summary of Peanut Vial Vitrified Solids \& Insert Calc Solids}

The coefficient of variation: $C V=100$ ( Standard Deviation ) Average

VITRIFIED SOLIDS

CALCINED

SOLIDS

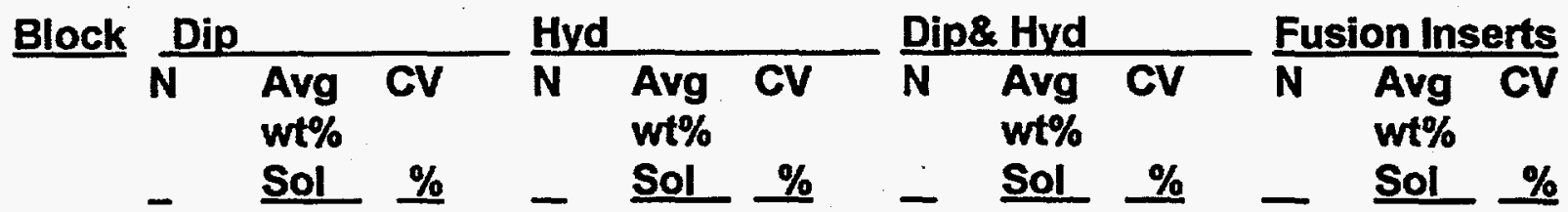

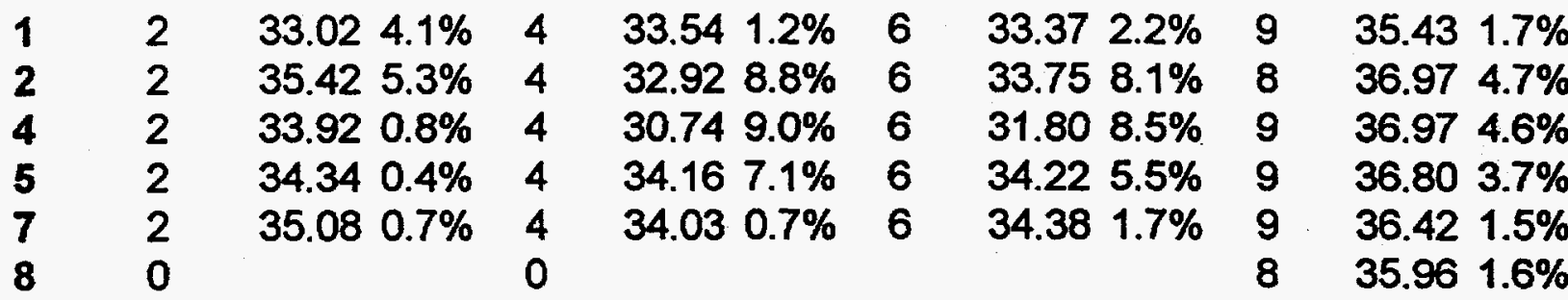

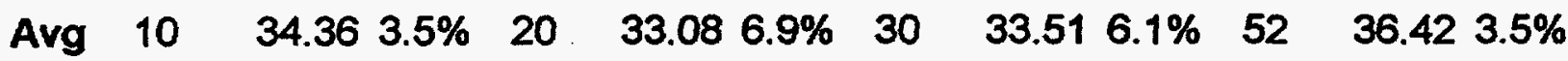




\section{Table 7}

ARG-1

( SRT-ASG-95-0081)

DWPF Historical Data from the Current Method

SCREENED for Outliers

Sample statistics based on individual analysis results.

Std: Sample standard Deviation

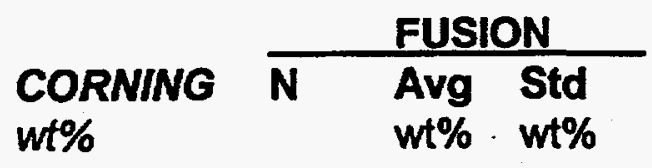

\begin{tabular}{lll} 
& \multicolumn{3}{l}{ MIXED ACID } \\
\hline $\mathbf{N}$ & $\begin{array}{l}\text { Avg } \\
\text { wt\% }\end{array}$ & $\begin{array}{l}\text { Std } \\
\text { wt\% }\end{array}$ \\
& & \\
393 & 2.43 & 0.071 \\
& & \\
392 & 1.05 & 0.046 \\
389 & 0.071 & 0.005 \\
398 & 0.006 & 0.006 \\
393 & 9.8 & 0.271 \\
391 & 2.30 & 0.085 \\
387 & 1.49 & 0.039 \\
397 & 0.52 & 0.017 \\
392 & 1.45 & 0.040 \\
392 & 8.53 & 0.246 \\
392 & 0.85 & 0.028 \\
386 & 21.8 & 0.908 \\
392 & 0.70 & 0.020 \\
391 & 0.102 & 0.004
\end{tabular}

Al 2.50

279

2.45

0.071

286

2.57

0.095

Ca 1.02

278

$\begin{array}{ll}0.98 & 0.067\end{array}$

272

0.0700 .006

276

0.0090 .006

277

9.6

0.253

277

2.22

0.076

$\begin{array}{llll}276 & 1.46 & 0.039\end{array}$

275

0.51

0.015

$\begin{array}{llll}280 & 1.43 & 0.039\end{array}$

$\mathrm{Na} \quad 8.53$

$\mathrm{Ni} \quad 0.83$

$\begin{array}{lll}279 & 0.82 & 0.026\end{array}$

$\begin{array}{llll}287 & 23.0 & 0.670\end{array}$

$\begin{array}{lll}280 & 0.68 & 0.018\end{array}$

391

0.1020 .004 


\section{Table 8}

MOCK-up Test Data

\section{ARG-1}

Sample statistics based on individual ARG-1 analysis results

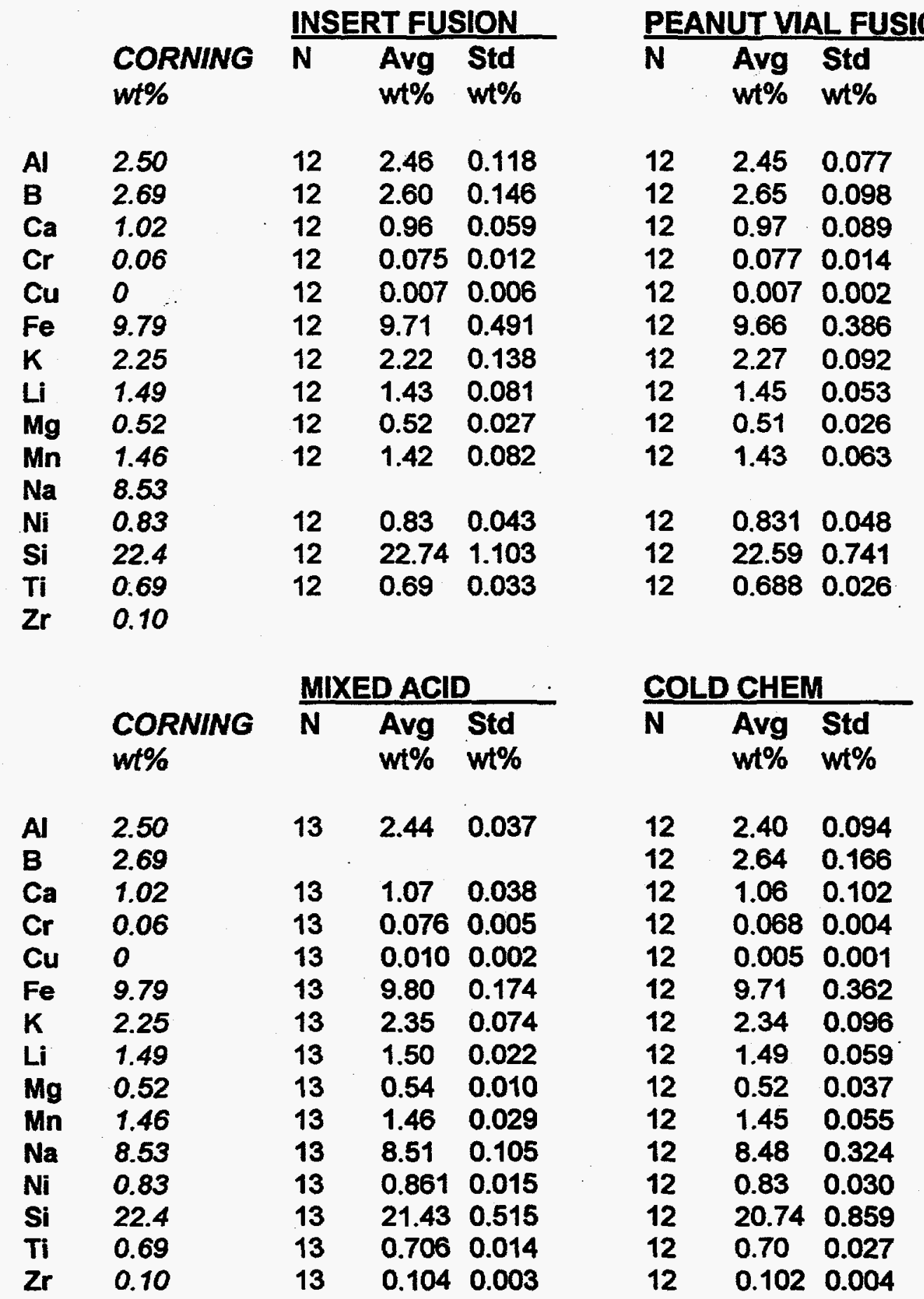


Table 9

MOCK-up Test Data

\section{BLANKS $\left(\times 10^{-3}\right)$}

Sample statistics based on individual blank analysis results $\left(\times 10^{-3}\right)$

\section{INSERT FUSION \\ N Mean Std $\mathrm{mg} / \mathrm{L} \mathrm{mg} / \mathrm{L}$}

$\begin{array}{lrrr}\mathrm{Al} & 12 & 11.8 & 9.7 \\ \mathrm{~B} & 12 & 6.8 & 28.6 \\ \mathrm{Ca} & 12 & -61.1 & 21.9 \\ \mathrm{Cr} & 12 & 11.7 & 13.0 \\ \mathrm{Cu} & 12 & 4.4 & 2.8 \\ \mathrm{Fe} & 12 & 96.1 & 188.1 \\ \mathrm{~K} & 12 & 29.4 & 24.2 \\ \mathrm{Li} & 12 & 1.8 & 1.0 \\ \mathrm{Mg} & 12 & 0.0 & 2.1 \\ \mathrm{Mn} & 12 & 2.5 & 3.2 \\ \mathrm{Ha} & & & \\ \mathrm{Hi} & 12 & 5.7 & 8.1 \\ \mathrm{Si} & 12 & -8.5 & 50.9 \\ \mathrm{Ti} & 12 & 4.9 & 2.7 \\ \mathrm{Zr} & & & \end{array}$

\section{MIXED ACID}

\section{N Mean Std} $\mathrm{mg} / \mathrm{L} \mathrm{mg} / \mathrm{L}$

$\begin{array}{lrrr}\text { Al } & 13 & 18.4 & 18.8 \\ \text { B } & & & \\ \mathrm{Ca} & 13 & 17.7 & 33.9 \\ \mathrm{Cr} & 13 & 6.5 & 4.2 \\ \mathrm{Cu} & 13 & 5.8 & 3.0 \\ \mathrm{Fe} & 13 & -1.8 & 12.2 \\ \mathrm{~K} & 13 & 121.4 & 42.8 \\ \mathrm{Li} & 13 & 3.4 & 1.4 \\ \mathrm{Mg} & 13 & 0.5 & 3.5 \\ \mathrm{Mn} & 13 & 1.0 & 0.6 \\ \mathrm{Ma} & 13 & 21.0 & 19.3 \\ \mathrm{Mi} & 13 & 0.5 & 10.9 \\ \mathrm{Si} & 13 & -10.6 & 202.9 \\ \mathrm{Ti} & 13 & 3.3 & 2.2 \\ \mathrm{Zr} & 13 & 2.2 & 2.4\end{array}$

\section{PEANUT VIAL FUSION}

$N$ Mean Std

$\mathrm{mg} / \mathrm{L} \mathrm{mg} / \mathrm{L}$

$\begin{array}{rrr}12 & 15.8 & 7.9 \\ 12 & 9.3 & 43.5 \\ 12 & -4.6 & 24.1 \\ 12 & 12.8 & 11.4 \\ 12 & 5.3 & 3.6 \\ 12 & 57.3 & 80.0 \\ 12 & 44.1 & 61.7 \\ 12 & 5.1 & 6.9 \\ 12 & 3.5 & 3.4 \\ 12 & 5.0 & 6.4 \\ 12 & 15.4 & 10.2 \\ 12 & -25.3 & 102.2 \\ 12 & 6.5 & 3.5\end{array}$

COLD CHEM

$N$ Mean Std

$\mathrm{mg} / \mathrm{L} \mathrm{mg} / \mathrm{L}$

61.8

$-46.1$

103.7

32.9

76.2

$1.8 \quad 3.0$

$1.3 \quad 1.7$

$29.0 \quad 34.5$

$42.7 \quad 43.9$

$0.4 \quad 1.9$

$5.4 \quad 3.7$

$\begin{array}{ll}0.8 & 0.8\end{array}$

$43.1 \quad 17.8$

$\begin{array}{ll}-0.5 & 11.9\end{array}$

$645.7 \quad 271.4$

$\begin{array}{ll}1.3 & 1.5\end{array}$ 


\section{Plot 1}

\section{Li/Fe Ratios for Insert Cold Chem}

Mult IPI Box-and-WhIakar Plot

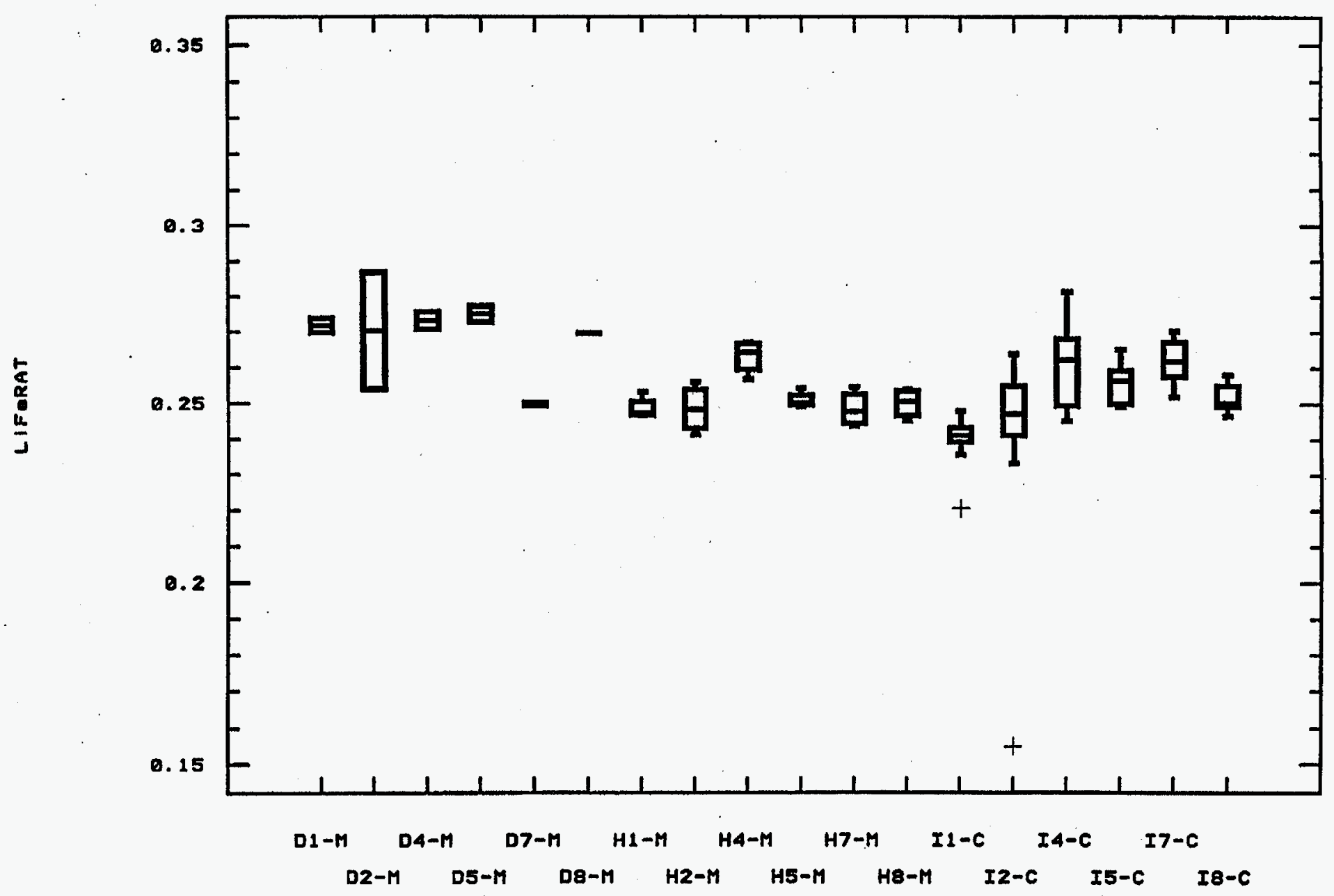

Blocks: 1 through 8, excluding Block 3 \& 6

D1-M,...,D8-M: Peanut Vial Dip Samples by Mixed Acid

H1-M,...,H8-M: Peanut Vial HydragardTM Samples by Mixed Acid

I1-C,...,I8-C: Insert Samples by Cold Chemical 


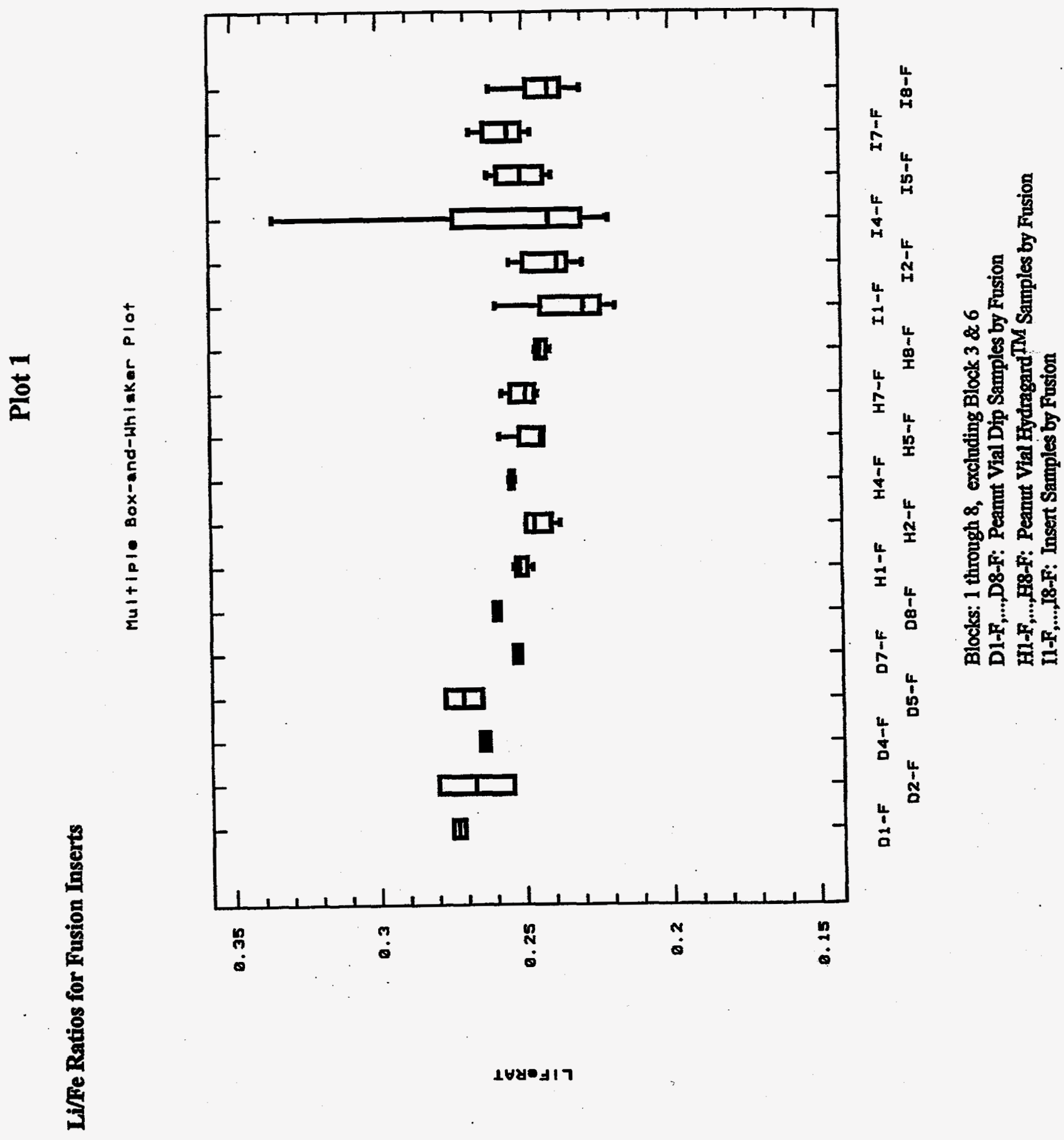




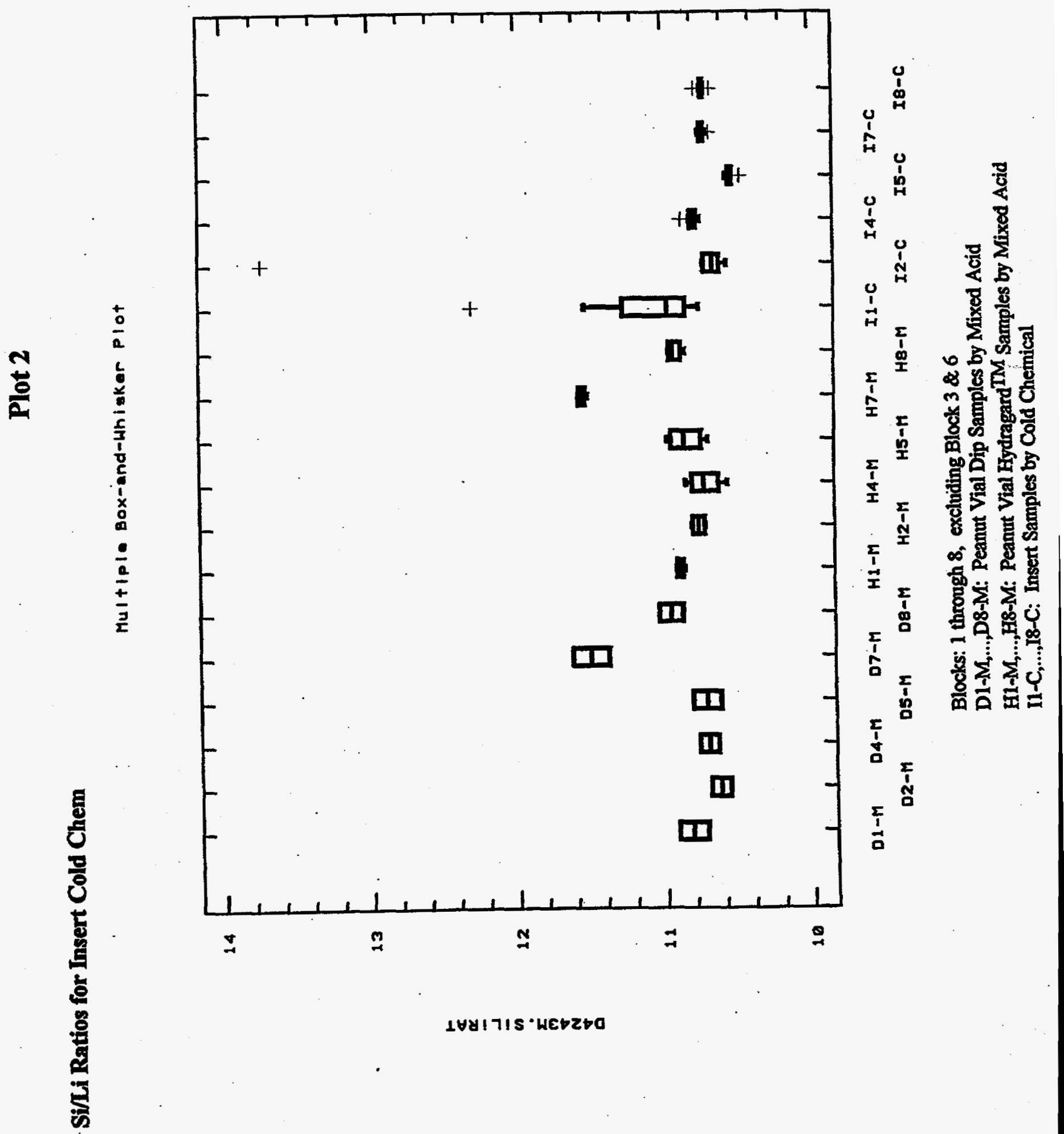




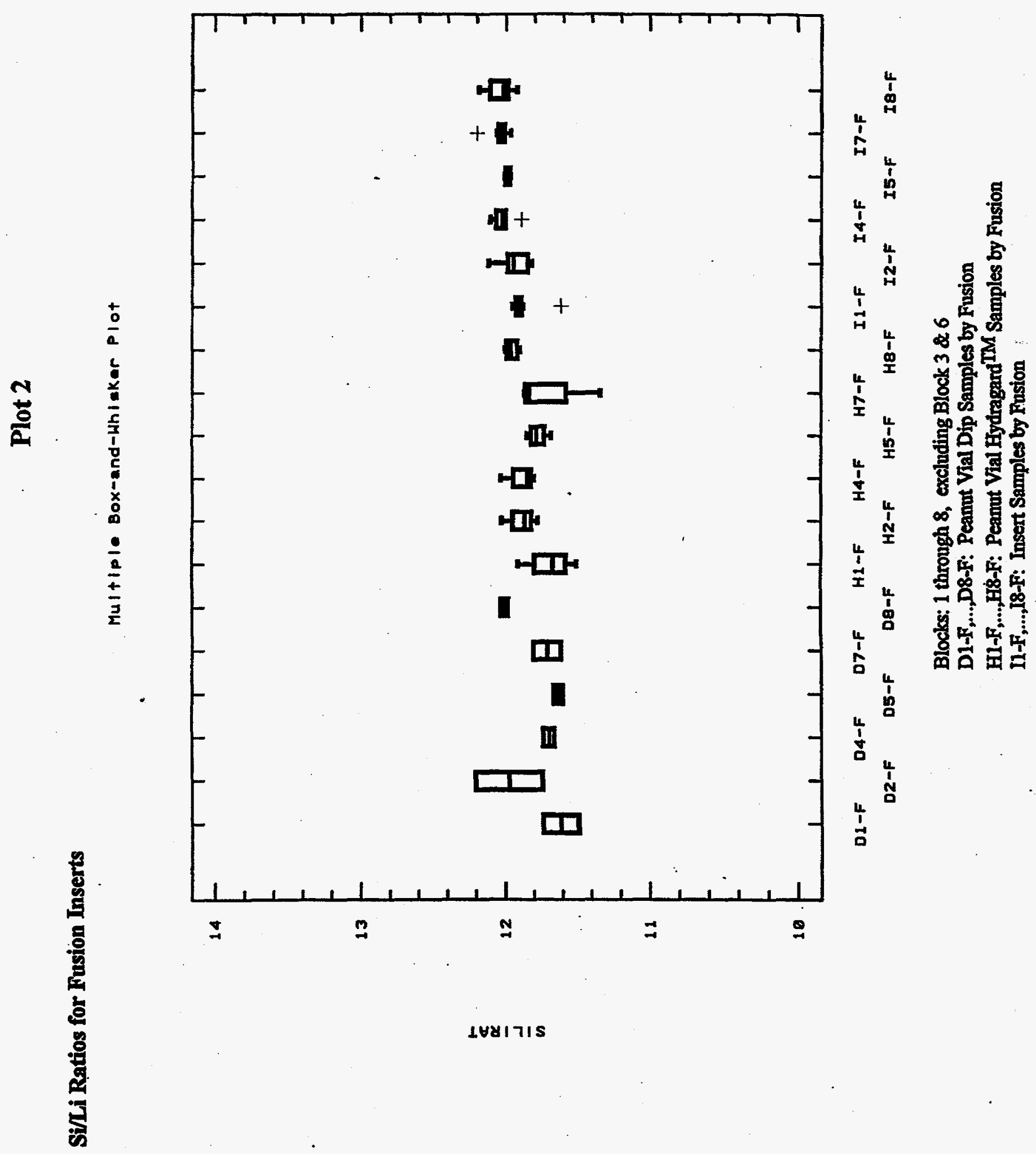




\section{Plot 3}

Page 37 of 49

Box-and Whisker Plots: Insert Cold Chemical (Calcine Corrected) Elemental wt\% data

Dip \& Eydragard Peanut Vials by Mixed Acld
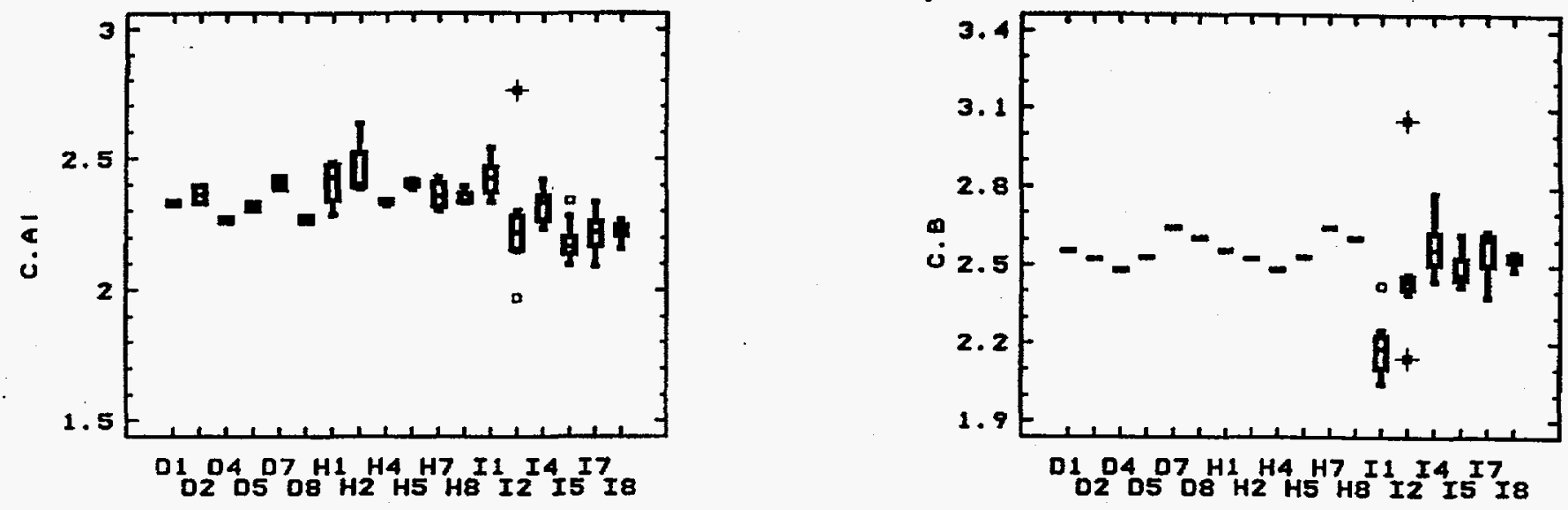

D \& H from Peanut Vial Fusion
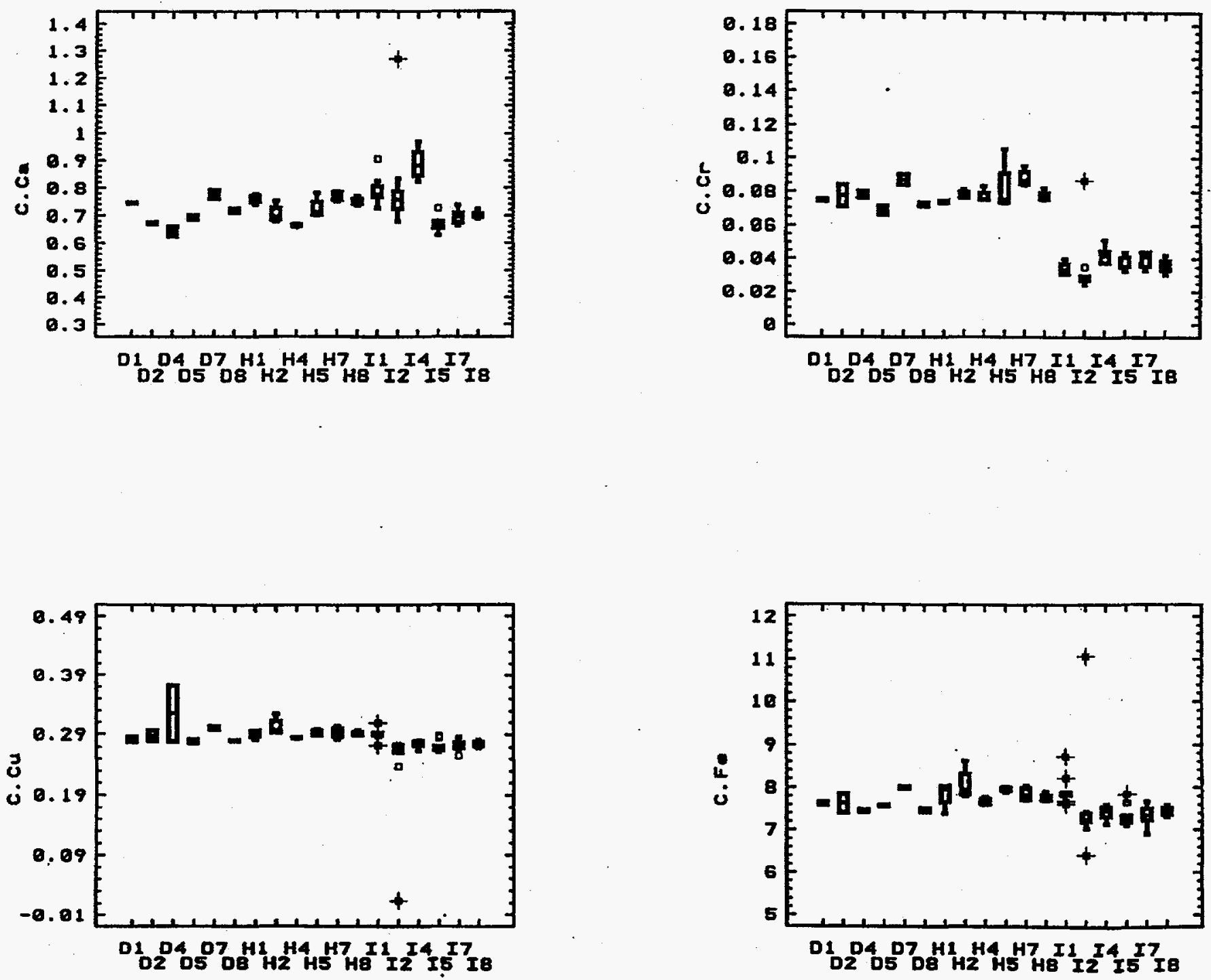
Box-and Whisker Plots: Insert Cold Chemical( Calcine Corrected) Elemental wt\% data

Dip \& Eydrngard Peanut Vals by Mized Acld
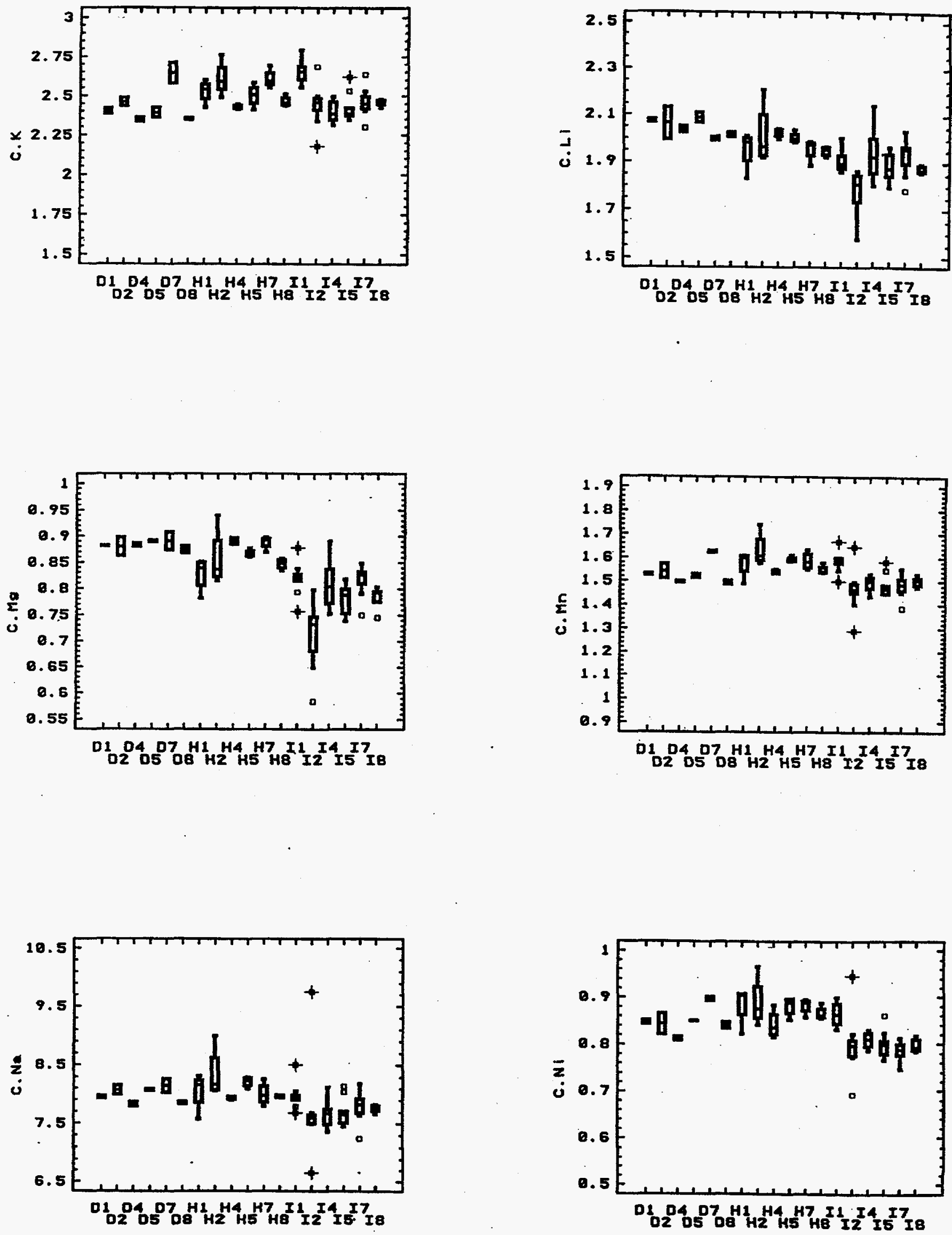
Plot 3

Box-and Whisker Plots: Insert Cold Chemical (Calcine Corrected) Elemental wt\% data

Dip \& Hydragard Peanat Vials by Mred Acld
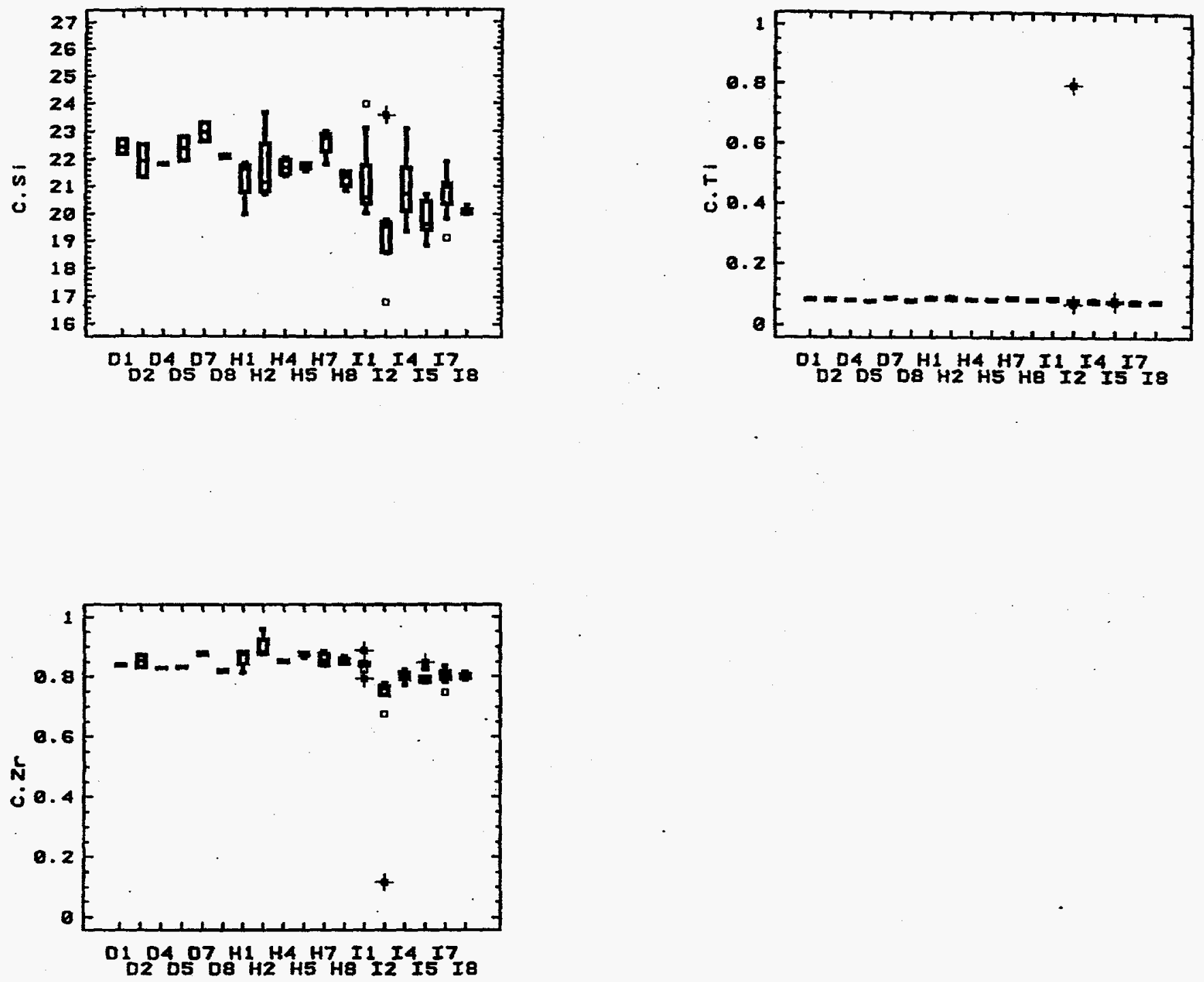


\section{Plot 4}

Box-and Whisker Plots: Insert Fusion( Calcined ) Elemental wt\% data

Dip \& Hydragard Peanut Vials by Fuston
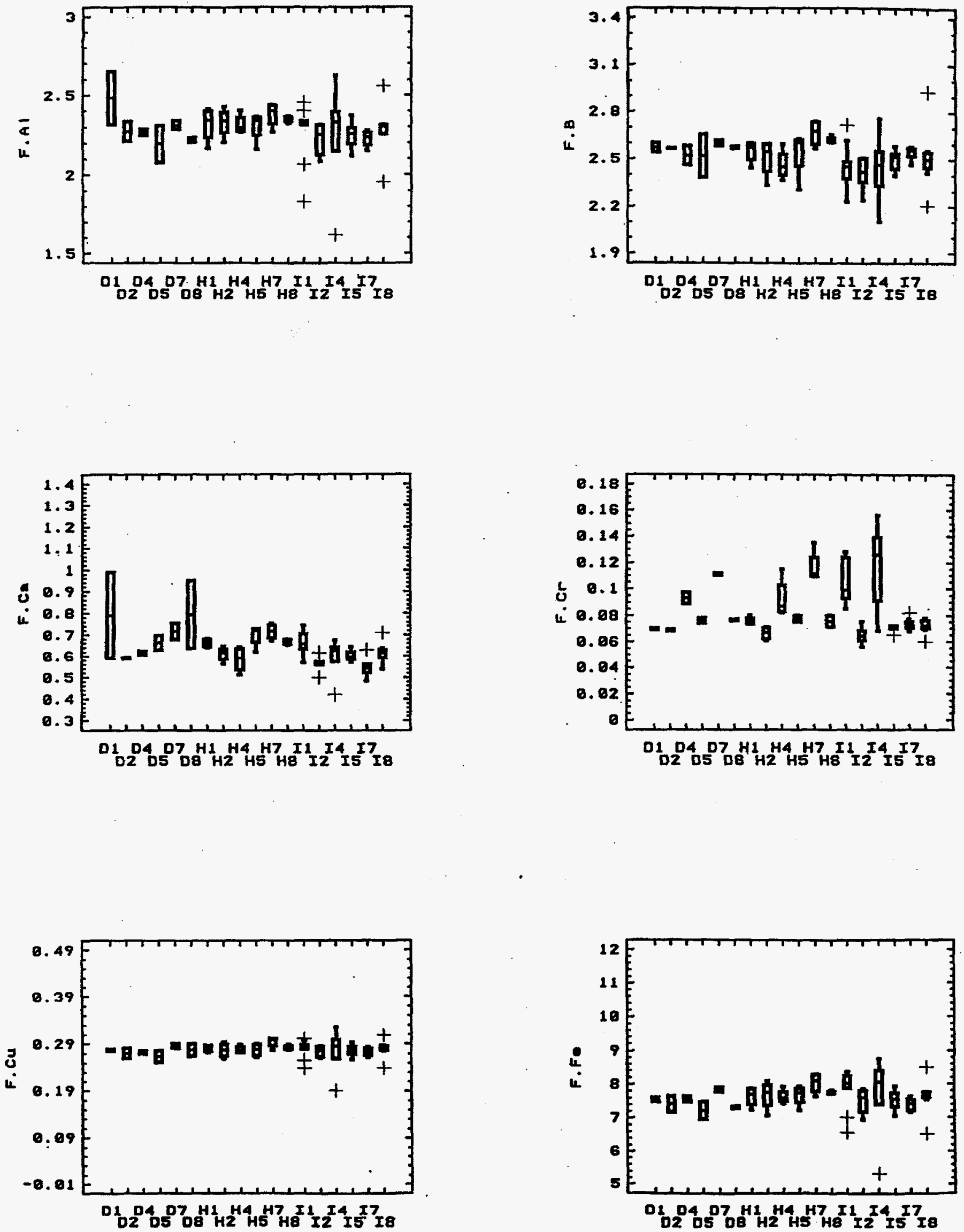


\section{Plot 4}

Page 41 of 49

Bor-and Whisker Plots: Insert Fusion( Calcined ) Elemental wt\% data Dip \& Hydragard Penant Vials by Fuslon
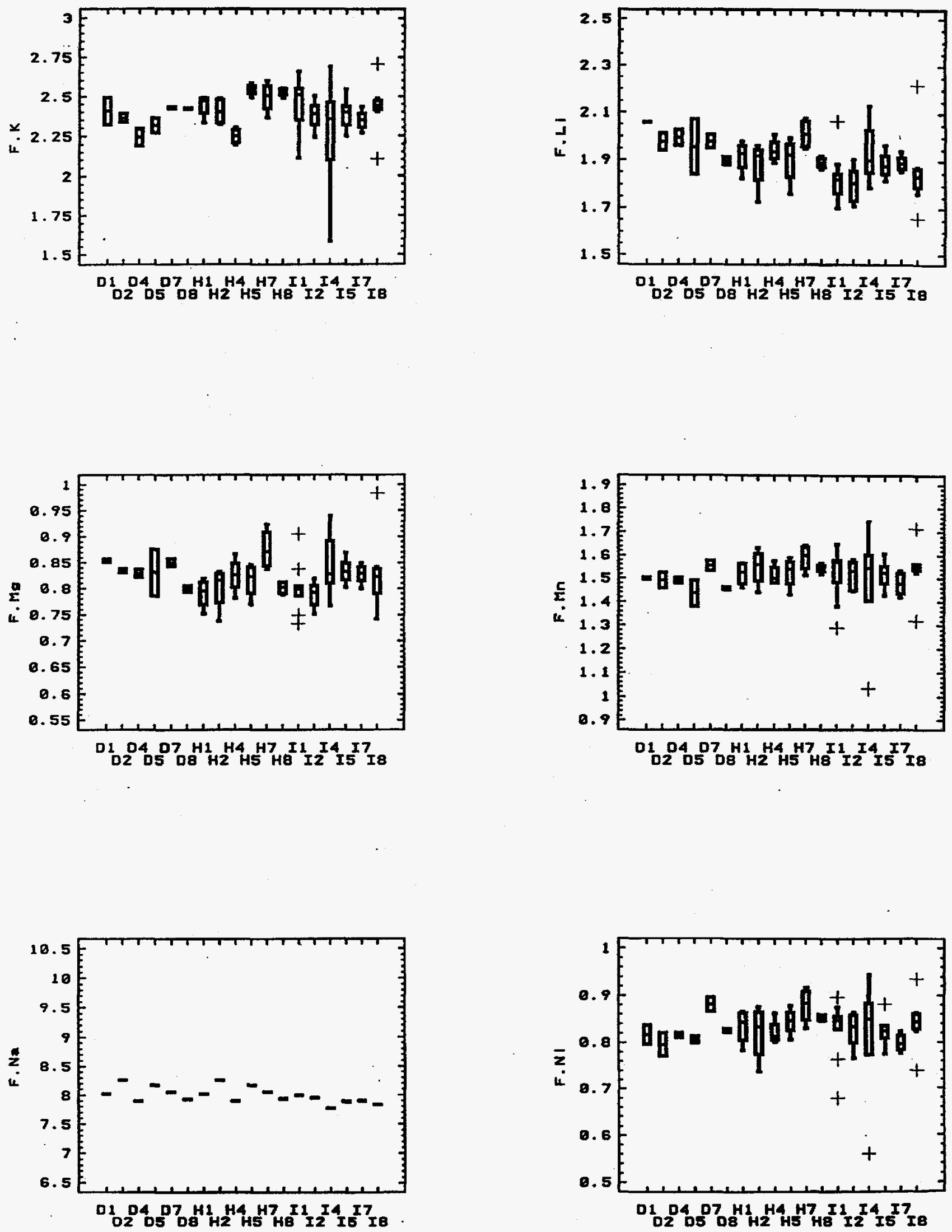

D E Hrom Mlxed Acid. I from Cold Chem 
Westinghouse Savannah River Company

Savannah River Technology Center

Aiken, SC 29808
WSRC-TR-97-00292

September 18, 1997

Page 42 of 49

Plot 4

Box-and Whisker Plots: Insert Fusion( Calcined ) Elemental wt\% data

Dip \& Eydragard Peanut Vials by Fusion
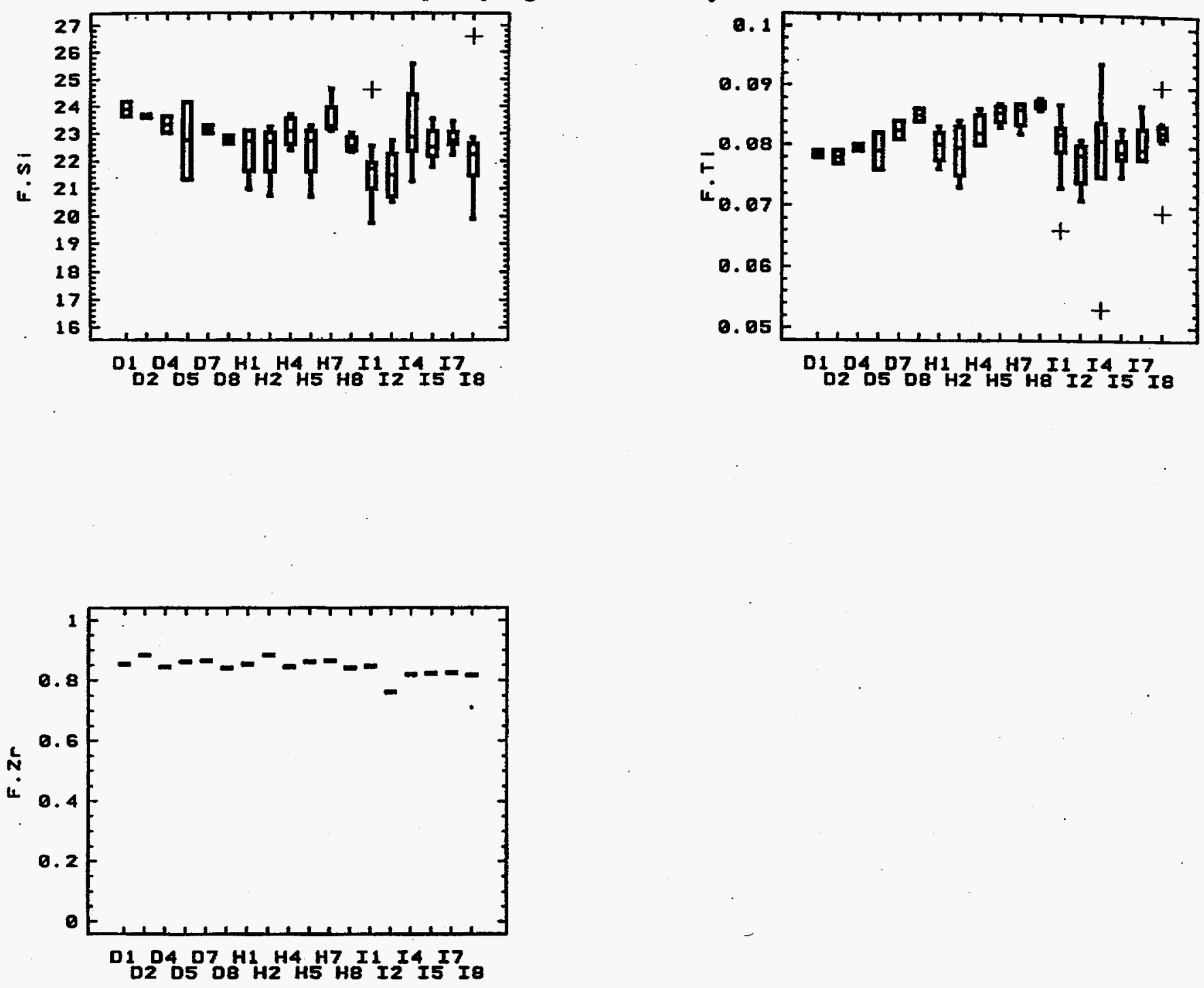

D \& H from Mixed AcId. I from Cold Chem 


\section{Plot 5}

Bor-and Whisker Plots: ARG-1 Elemental wt\% data \& Coming wt\%"
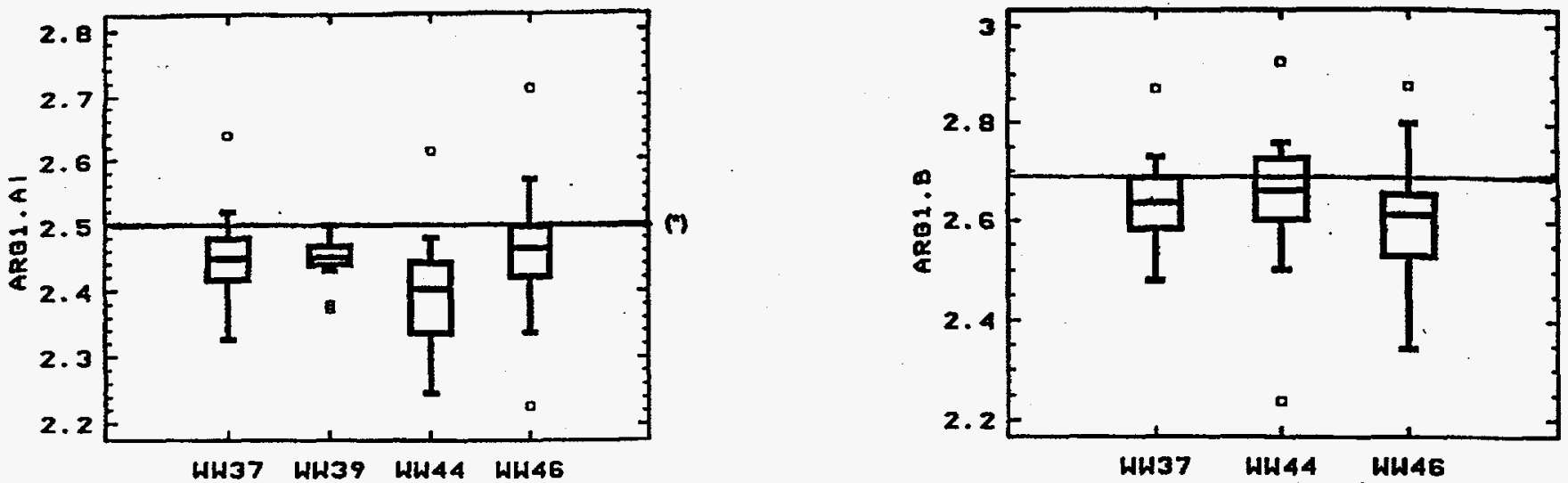

WW37: ARG-1, by Fusion, run with Peanut Vial Samples WW39: ARG-1, by Mired Acid, run with Peanut Vial Samples WW44: ARG-1, by Cold Chem, run with Insert Cold Chem Samples WW46: ARG-1, by Fusion, run with Fusion Inserts
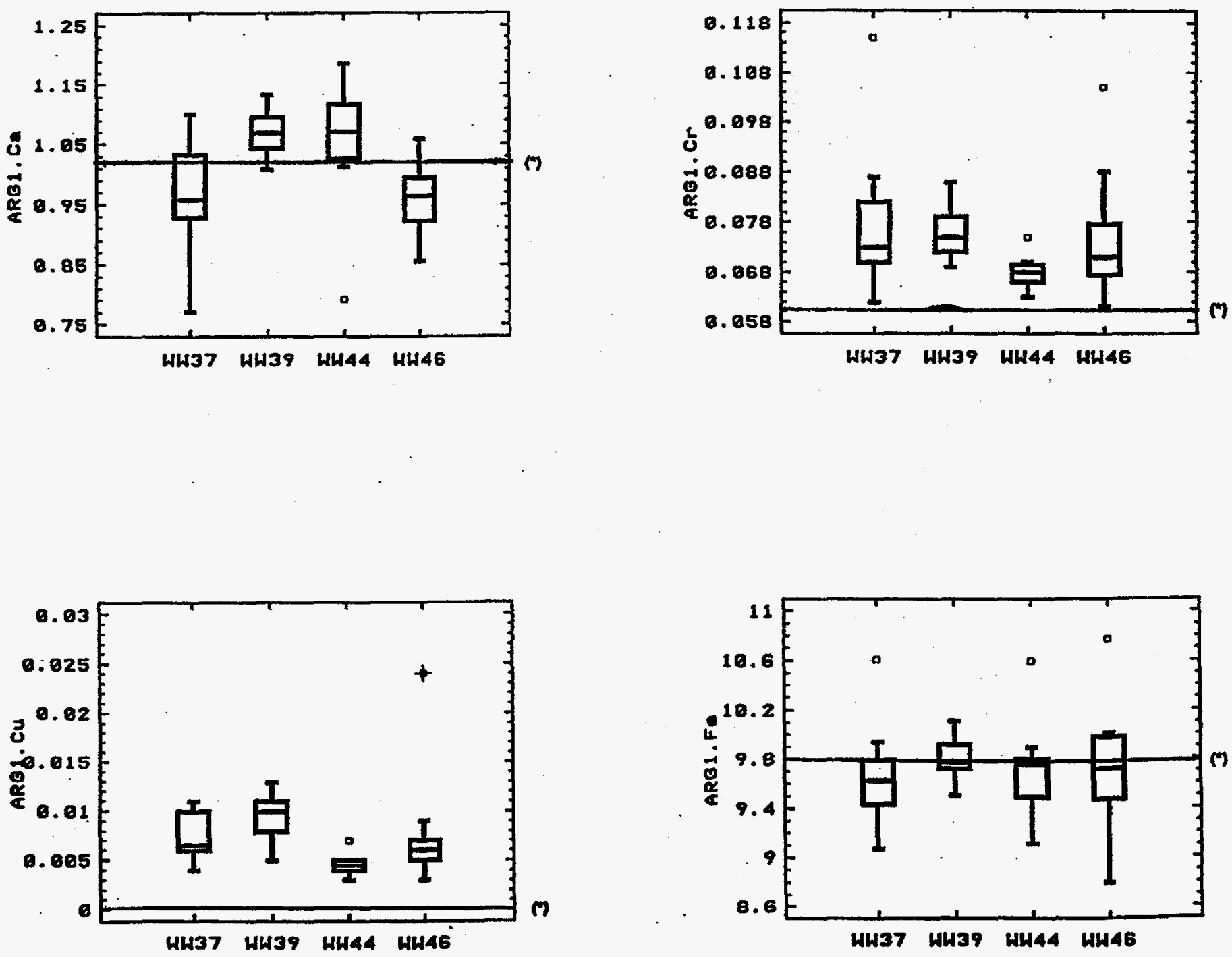


\section{Plot 5}

Box-and Whisker Plots: ARG-1 Elemental wt\% data \& Coming wt\%"
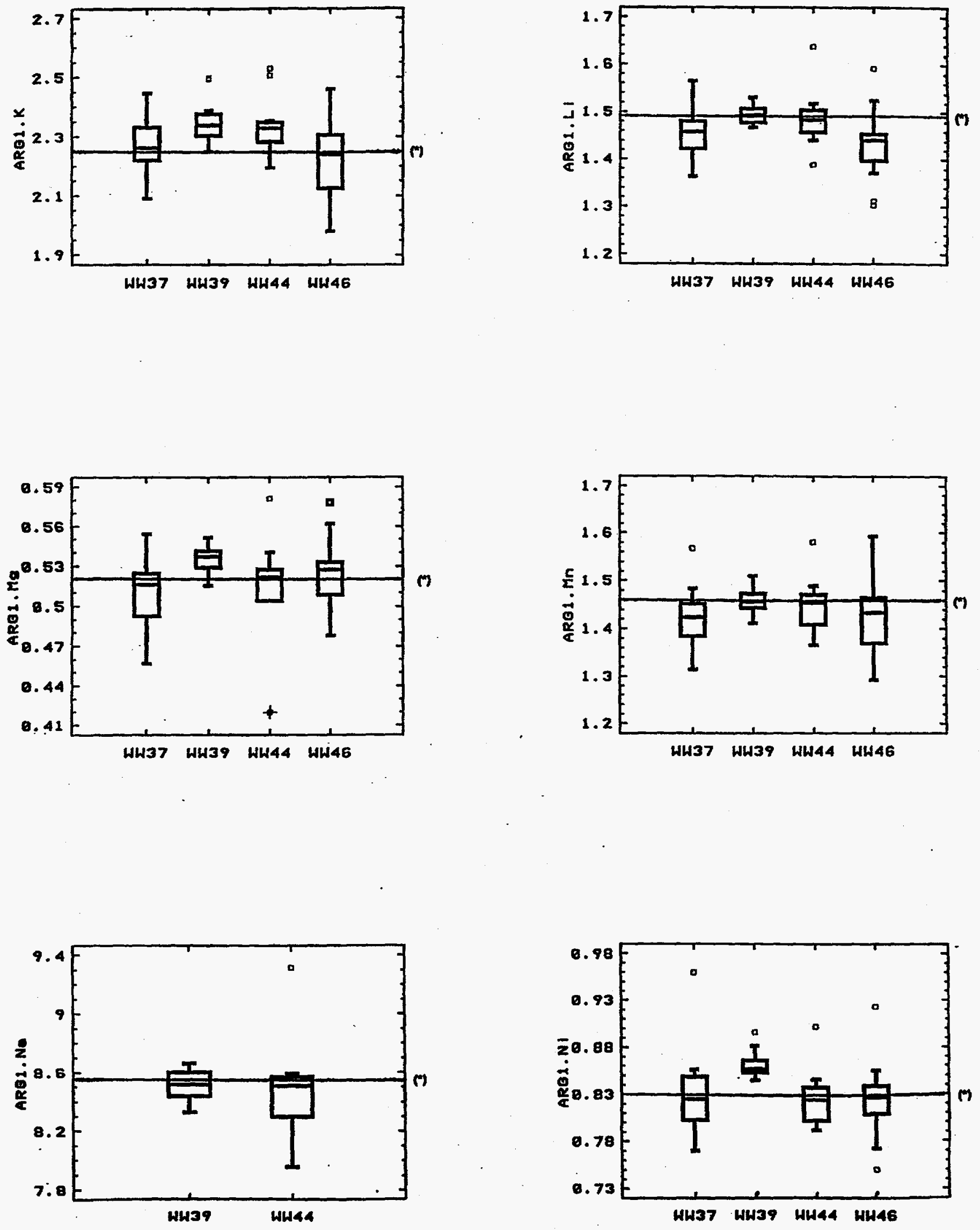


\section{Plot 5}

Bor-and Whisker Plots: ARG-1 Elemental wt $\%$ data $\&$ Coming wt\%
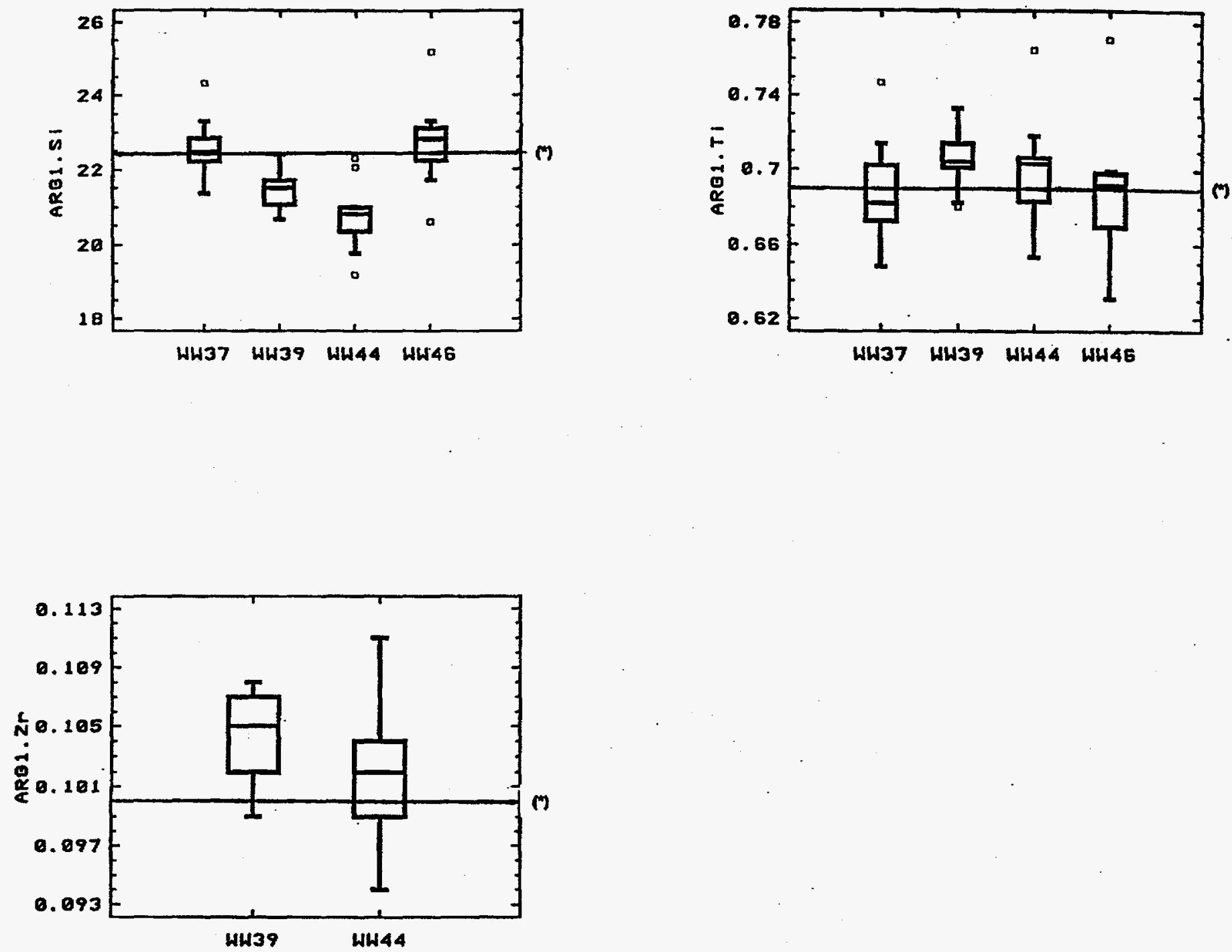


\section{Plot 6}

Bor-and Whisker Plots: Blank Elemental data(mg/L)
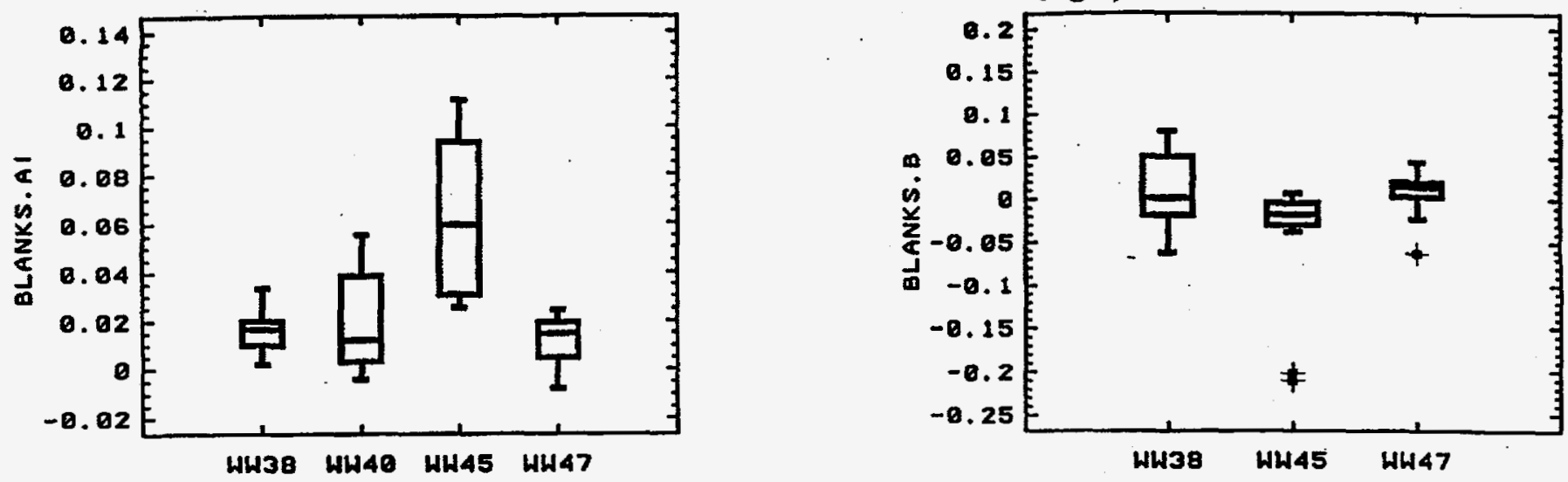

WW38: Blanks, by Fusion, run with Peanut Vial Samples WW40: Blanks, by Mired Acid, run with Peanut Vial Samples WW45: Blanks, by Cold Chem, run with Insert Cold Chem Samples WW47: Blanks, by Fusion, run with Fusion Inserts
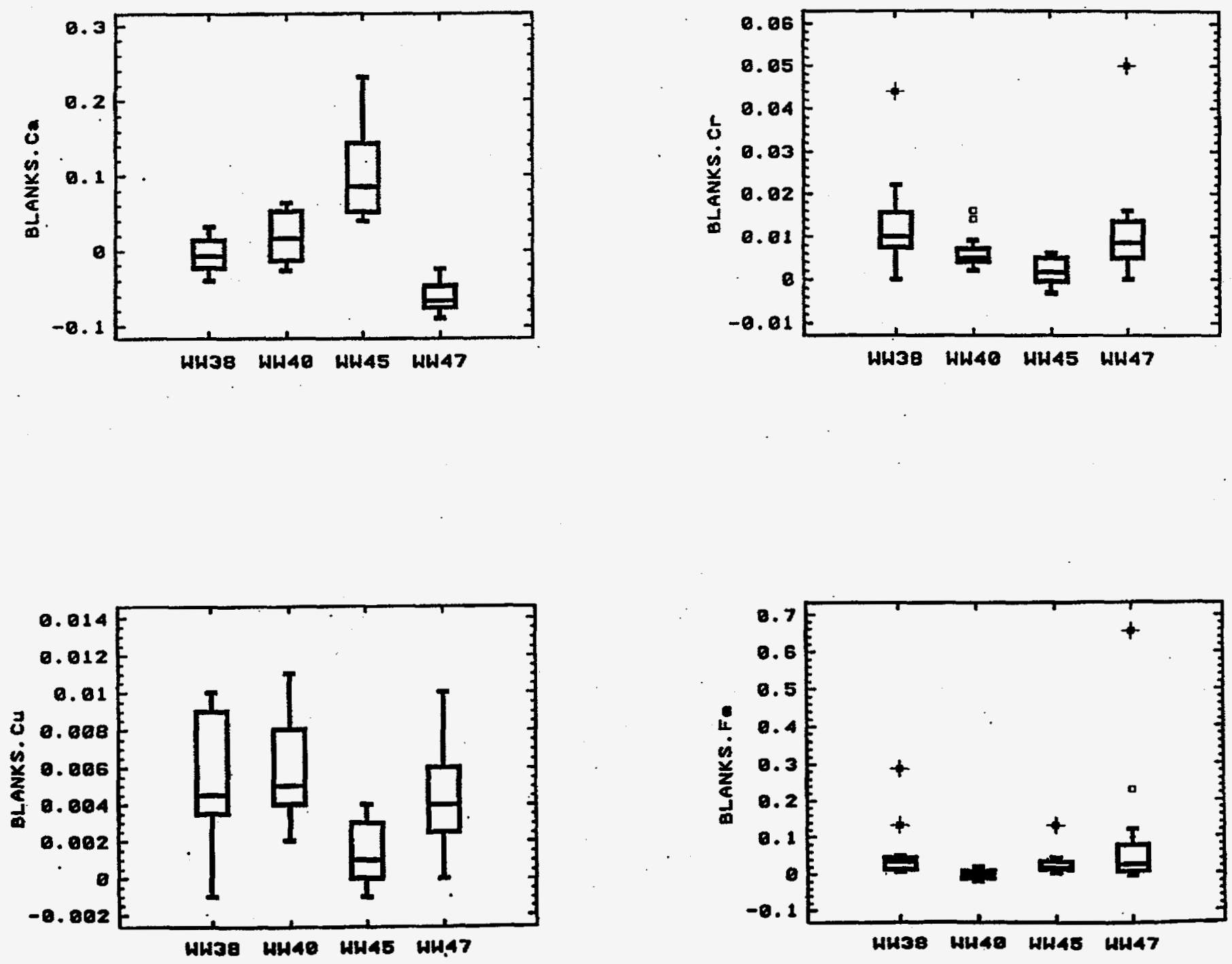


\section{Plot 6}

Box-and Whisker Plots: Blank Elemental data(mg/L)
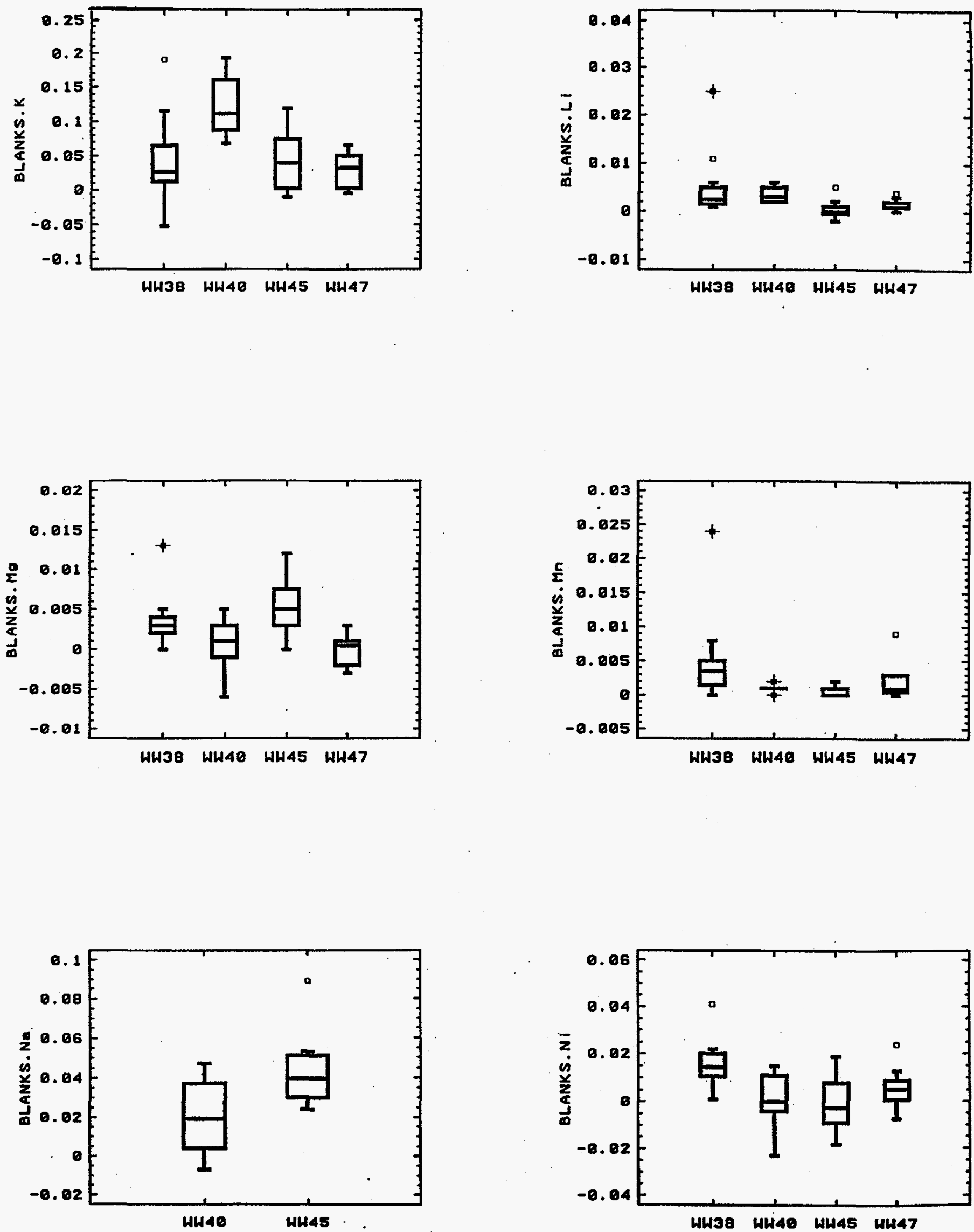


\section{Plot 6}

Box-and Whisker Plots: Blank Elemental data(mg/L)
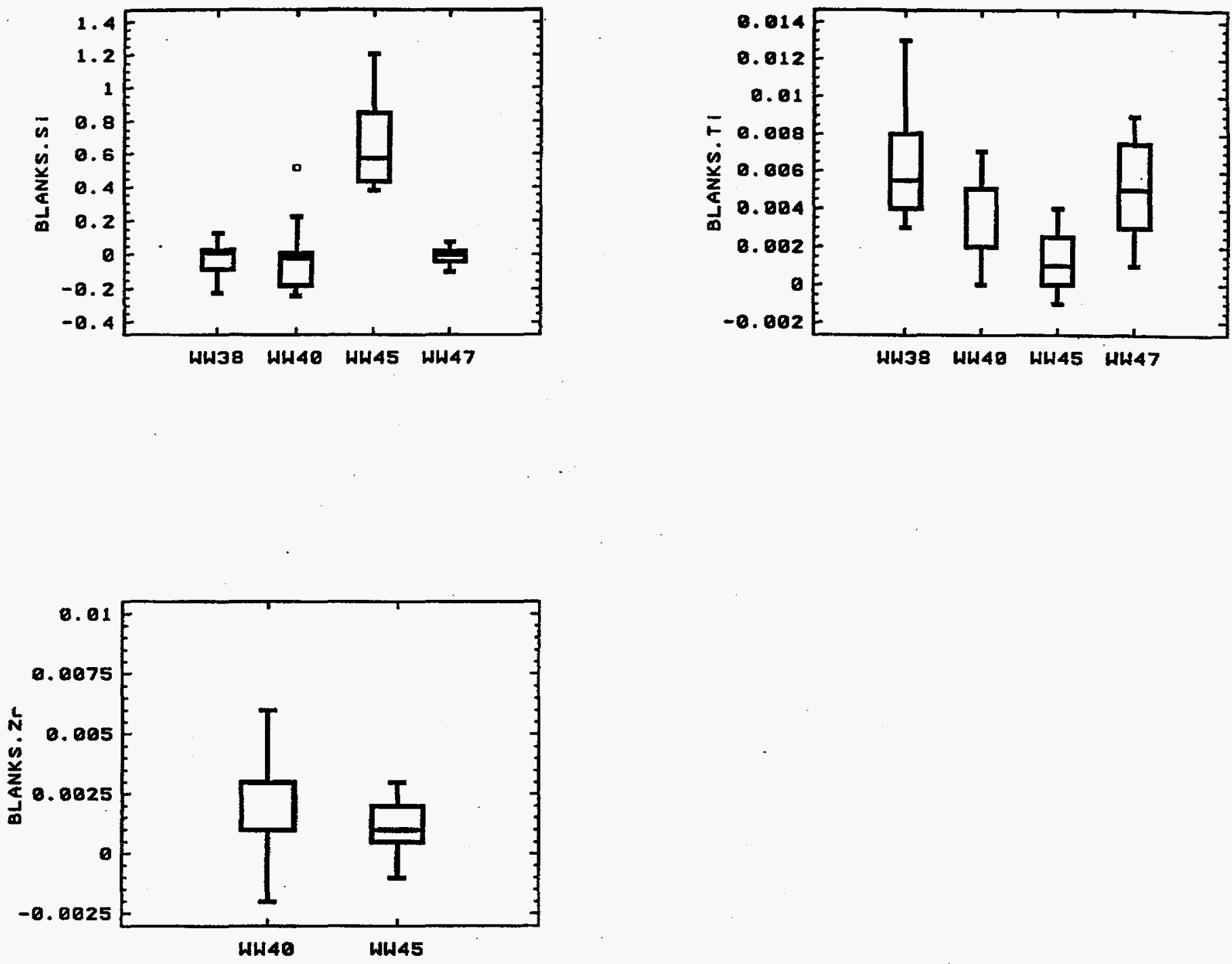
Box-and Whisker Plots: wt\% Total Solids, wt\% Vitrified and wt\% Calcined data

WW41: Fusion Inserts

WW43: Peanut Vials- Dip \& Hydragard

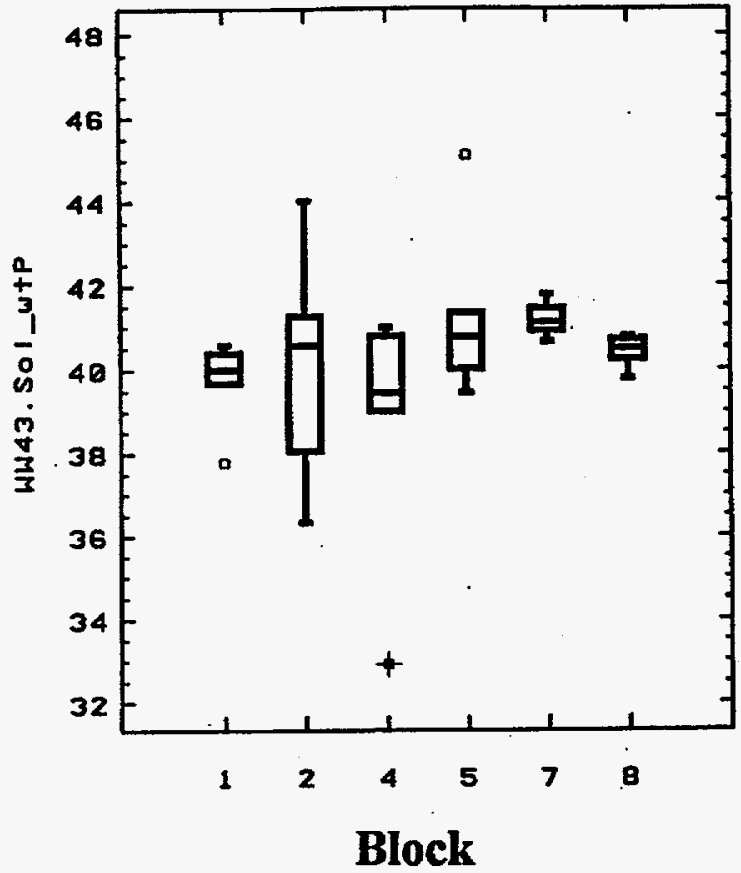

WW43: Peanut Vials- Dip \& Hydragard

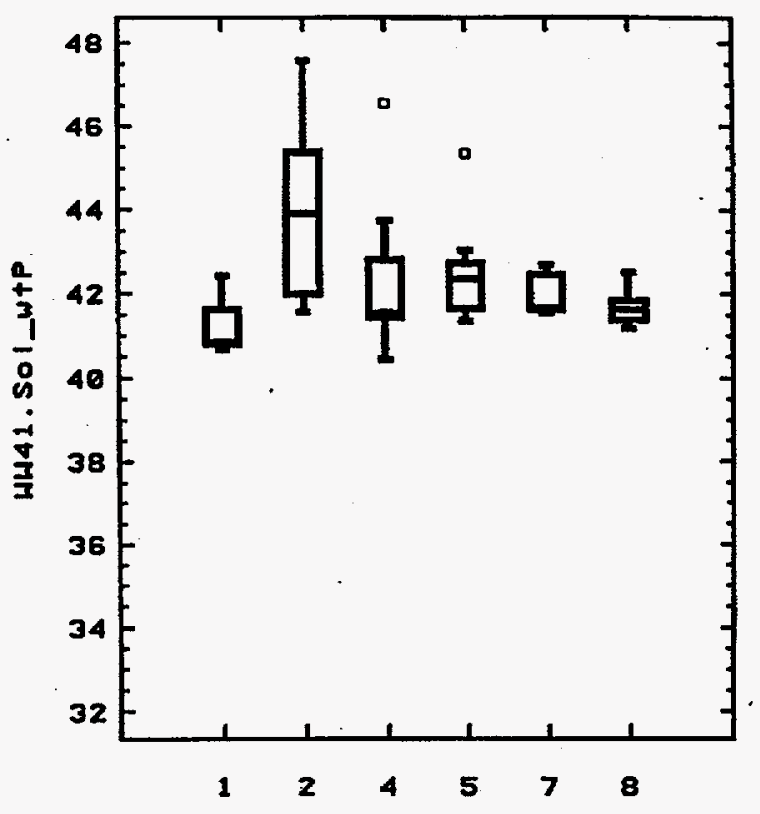

Block

Ww41: Fusion Inserts

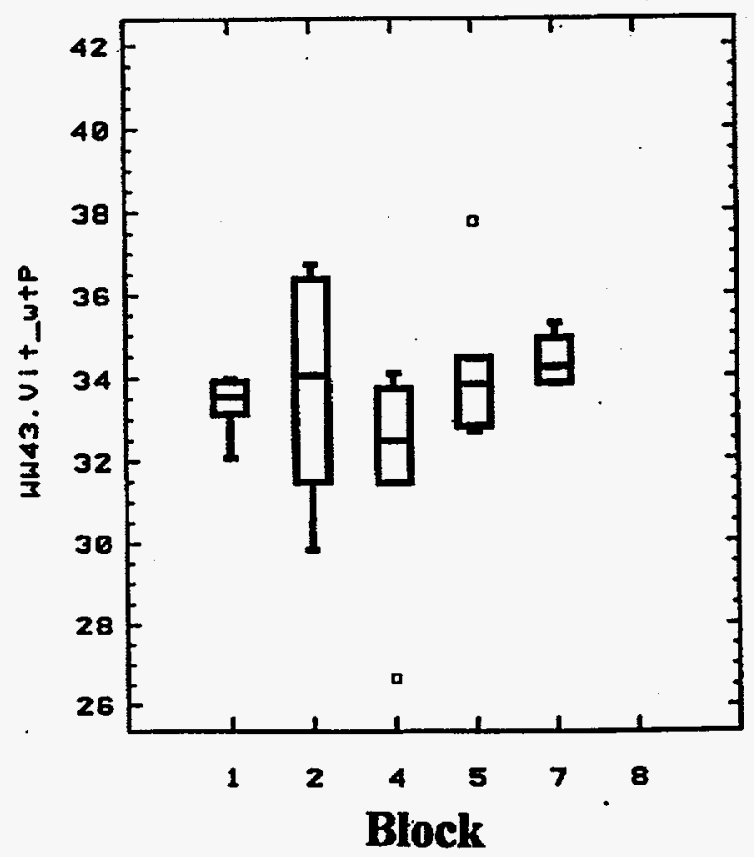

WW43: Peanut Vials- Dip \& Hydragard

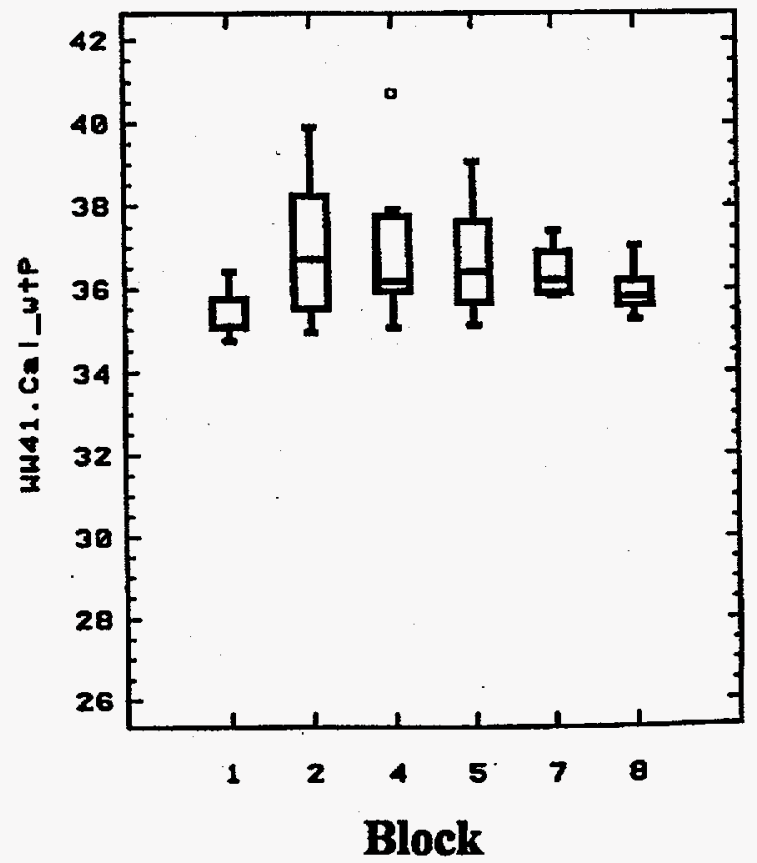

WW41: Fusion Inserts 